\title{
THE DEVALUATION OF NONWHITE COMMUNITY IN REMEDIES FOR SUBSIDIZED HOUSING DISCRIMINATION
}

\author{
MICHAEL R. TEIN†
}

\section{INTRODUCTION}

This Comment argues that judicial treatment of discrimination in subsidized housing has not accorded proper respect to nonwhite community as a legitimate entity. ${ }^{1}$ Unwarranted exercise of judicial restraint, despite a broad mandate from the Supreme Court, ${ }^{2}$ combined with the courts' binary understanding of the problem and its solution have resulted in an institutional failure to recognize discrimination in the remedial administration of federally assisted housing programs.

\section{A. The Problem: Discriminatory Site Selection and Tenanting}

Government programs for helping the poor to afford adequate shelter appear to have been primarily intended to address political and economic problems of class mobility under capitalism. ${ }^{3}$ This

† B.A. 1988, Yale College; J.D. Candidate 1992, University of Pennsylvania.

1 The term "subsidized housing" here denotes project-based housing assistance provided through federally funded production-oriented programs, including the Public Housing program, see infra note 4, the Section 8 New Construction and Substantial Rehabilitation programs, see infra note 49; the Section 236 mortgage interest subsidy program, $\S 236$ of the National Housing Act, 12 U.S.C. $\$ 1715 z-1$ (1988); the Section 202 program, $\S 202$ of the Housing Act of 1959, 12 U.S.C. $\S 1701 \mathrm{q}$ (1988); the Section 221(d)(3) Below Market Interest Rate program, $\S 221(d)(3)$ of the National Housing Act, 12 U.S.C. § 1715L(d)(3); and the Section 515 mortgage interest subsidy program administered by FmHA, $\S 515$ of Title $V$ of the Housing Act of 1949, 42 U.S.C. $\$ 1485$ (1988). See generally CONGRESSIONAL BUDGET OFFICE, CURRENT HOUSING PROBLEMS AND POSSIBLE FEDERAL RESPONSES 2932 (1988).

${ }^{2}$ See Hills v. Gautreaux, 425 U.S. 284, 306 (1976) (permitting a federal trial court to extend relief beyond the limits of the city where the discrimination actually occurred).

${ }^{3}$ There is a tendency to view subsidized housing problems only in terms of class, thereby disputing the notion that the disproportionate number of nonwhites in assisted housing is caused by societal discrimination, and dismissing suburban resistance to public housing as rooted in class differences, rather than racial antagonism. See, e.g., Lisa Foderado, Defiant Four: Councilmen Who are Blocking the Yonkers Housing Plan, N.Y. TIMEs, Aug. 31, 1988, at B6 (reporting claims of Yonkers City Council members that they were resisting public housing residents because they would be low income, not because they would be minority), discussed in Martha Mahony, Note, Law and Racial Geography: Public Housing and the Economy in New 
was the framework within which Congress first initiated public housing in $1937 .^{4}$ The entrenched racism in employment, ${ }^{5}$ education, ${ }^{6}$ and the private housing market, ${ }^{7}$ however, created the

Orleans, 42 STAN. L. REV. 1251, 1253 (1990).

${ }^{4}$ See United States (Wagner-Steagall) Housing Act of 1937, Pub. L. No. 75-412, 50 Stat. 888 (codified as amended at 42 U.S.C. \$ 1437a-j (1988)). In the New Deal environment, public housing under the Wagner-Steagall Act was viewed as a way station for the hard-hit members of the previously secure middle class, and aimed primarily "to alleviate present and recurring unemployment." DAVIS MGENTIRE, RESIDENGE AND RACE 291-92 (1960); see also LEONARD FREedMAN, PUBLIC HOUSING: THE POLITICS OF POVERTY 2, 100-04 (1969).

${ }^{5}$ The movement of jobs from the cities to the suburbs, in conjunction with the simultaneous racial polarization of the regions, has contributed to increased unemployment among nonwhites. See Mark Schneider \& $c$ Thomas Phelan, Blacks and Jobs: Never the Twain Shall Meet?, 26 URB. AFF. Q. 299, 299-301 (1990). Before 1945, most factories were located in the cities; by 1981 two-thirds of all manufacturing took place in the suburbs. For example, between 1970 and 1980, Philadelphia lost 140,000 jobs, many from the closing or relocation of local mainstay manufacturers. See KENNETH T. JAGKSON, CRABgRASS FrontIER: THE SUBURBanIZATION OF THE UNITED STATES 266-71 (1985). Samuel J. Simmons, former Assistant Secretary for Equal Opportunity of HUD, stated:

"As Whites have left the cities, jobs have left with them. After 1960, threefifths of all new industrial plants constructed in this country were outisde [sic] of central cities. In some cases as much as $85 \%$ of all new industrial plants located outside central cities were inaccessible to Blacks and other minorities who swelled ghetto populations."

Gautreaux v. Chicago Hous. Auth., 503 F.2d 930, 938 (7th Gir. 1974) (citation omitted) (quoting Assistant Secretary Simmons).

${ }^{6}$ See Jonathan Kozol, SAVAGE INEQUALTIIES: ChILDREN IN AMERICA's Schools 83-99 (1991). Thirty-eight years of public school desegregation orders have had little effect on the vast discrepancies between the public education of nonwhite and white students. Kozol's study cites as an example District 10 in New York City. Spacious P.S. 24, serving the district's predominantly white neighborhood of Riverdale, boasts an eighth-grade reading level for its average sixth grader. P.S. 79, with a $99 \%$ nonwhite student body, holds classes in a gymnasium; P.S. 261, which is $90 \%$ AfricanAmerican and Hispanic, is housed in a windowless converted rollerskating rink; and in P.S. 94, in the North Bronx section of District 10, 1300 sțudents study in a building designed for 700 and sit in classrooms where enough of the ceiling has collapsed that rain leaks in. See id. Differences among the 32 school districts in New York City are even more marked: affluent districts are funded at a rate 14 times higher than their poorer counterparts. See id. at 98 . A recent Community Service Society report points out that "it is inescapable that these inequities are being perpetrated on [school] districts which are virtually all black and Hispanic" and are the result of, at the very least, "systemic bias." See id. at 99 (quoting COMMUNITY SERV. SOC'Y OF N.Y., PROMOTING POVERTY: THE SHIFT OF RESOURCES AWAY FROM LOW-INCOME NEW YORK CITY SCHOOL DISTRICTS (1987)).

${ }^{7}$ Despite legal prohibitions under the Fair Housing Act against discrimination in the sale or rental of housing, race-based obstacles still confront nonwhites who search for private housing. Racial steering, redlining, and acts of racial intimidation continue to frustrate minority housing consumers. See, e.g., Alan Finder, Racism and Arson: A New Chapter in an Old Story, N.Y. TIMES, Feb. 11, 1990, at 40 (reporting that 
economic frictions that enabled a correlation between class and race. The complexion of subsidized housing has reflected these frictions: presently, the majority of persons receiving rental assistance are nonwhite. ${ }^{8}$

Residential segregation in both the federally assisted and private markets is pervasive. ${ }^{9}$ The postwar era has witnessed a polarization in housing patterns, with the suburbs predominantly white and the central cities nonwhite. ${ }^{10}$ Under Plessy $v$. Ferguson ${ }^{11}$ public housing was legally segregated by project and nonwhite projects were located in nonwhite urban areas. ${ }^{12}$ Even after Brown v. Board of

racially motivated arson destroyed a house purchased two weeks earlier by the first African-American family on an all-white block in Brooklyn). See generally JoHn F. KaIN \& JOHN M. QUIGLEY, HOUSING MARKETS AND RACIAL DISCRIMINATION: A MICROECONOMIC ANALYSIS 56-91 (1975) (discussing economic effects of discriminatory practices in the private housing market). Nonwhites pay more for equivalent housing than do whites and are more likely to be denied mortgage loans than whites with similar financial profiles. See, e.g., Mary R. Jackman \& Robert W. Jackman, Racial Inequalities in Home Ownership, in RACE, ETHNICITY, AND MINORITY HOUSING IN THE UNITED STATES 39, 48 (Jamshid A. Momeni ed., 1986) (noting that racial discrimination accounts for price differentials between comparable homes owned by AfricanAmericans and whites); see also BOARD OF GOVERNORS OF THE FED. RESERVE SYSTEM, REDLINING: RESEARCH AND FEDERAL LEGISLATIVE RESPONSE 8-10 (1982) (summarizing several studies indicating that nonwhite applicants are more likely to be denied mortgage loans that their similarly situated white counterparts).

8 In 1979, HUD determined that $47.1 \%$ of low-income housing project residents were African-American, $38.4 \%$ were white, $12.2 \%$ were Hispanic, $1.5 \%$ were Native American, 0.5\% were Asian-American, and 0.5\% were "other minorities." See U.S. DEP'T OF HOUS. AND URBAN DEV., 1979 STATISTICAL YEARBOOK 206 (1979) (table 64). In 1989, HUD statistics indicated that of the 2.4 million residents of housing authority-owned units, $39.8 \%$ were African-American, and $12.4 \%$ were Hispanic. Of the 1.4 million receiving demand subsidies, $34.0 \%$ were African-American and $10.6 \%$ were Hispanic. See U.S. DEP'T OF COMMERGE \& U.S. DEP'T OF HOUS. AND URBAN DEV., CURRENT HOUSING REPORTS: AMERICAN HOUSING SURVEY FOR THE UNITED STATES IN 1989, at 58 (1990).

9 To attain complete integration of the large metropolitan regions, in 1980, an average of $79 \%$ of African-Americans, $48 \%$ of Hispanics, and $43 \%$ of Asian-Americans would have needed to move from their 1980 residences. See George C. Galster, Federal Fair Housing Policy: The Great Misapprehension, in BUILDING FoundaTIONS: Housing AND Federal Policy 137 (Denise DiPasquale \& Langley C. Keyes eds., 1990) [hereinafter BUILDING FouNDATIONS].

${ }^{10}$ See U.S. CoMM'N ON CIVIL RIGHTS, HousING 1-6 (1961) (describing the isolation of nonwhites in the central cities and whites in surrounding suburbs as a "white noose"). See generally JAMEs A. KUSHNER, APARTHEID IN AMERICA: AN HISTORICAL AND LEGAL ANALYSIS OF CONTEMPORARY RACIAL SEGREGATION IN THE UNITED STATES 20-30 (1980) (discussing changes in housing patterns since World War II).

11 163 U.S. 537 (1896).

12 See KusHNER, supra note 10, at 31-32; ROBERT C. WEAVER, THE NEGRo GHETTO 73, 143-44, 159 (1948). Alexander Polikoff notes: 
Education, ${ }^{13}$ local public housing authorities continued to segregate projects based on race and to build public housing primarily in nonwhite neighborhoods unless the project was aimed at housing whites. ${ }^{14}$ The result is that most subsidized housing is located in urban centers, with the small amount of suburban stock confined mostly to nonwhite tracts. ${ }^{15}$

\section{B. The Conflicting Goals of the Fair Housing Act ${ }^{16}$}

The stated purpose of the Fair Housing Act (FHA) is "to provide, within constitutional limitations, for fair housing throughout the United States."17 No Supreme Court opinion precisely defines "fair housing," although the Court has emphasized that racial integration is both important and desirable. ${ }^{18}$ There are two views of the goals of the FHA: one, it aims only to eliminate discrimination; ${ }^{19}$ and two, it is designed to eliminate discrimina-

Because the black population of the central cities had grown enormously during the war years and had continued to increase in the $50 \mathrm{~s}$ and early $60 \mathrm{~s}$, in the larger cities the new public housing would serve a heavily black clientele. In the mores of the times it was therefore put in black neighborhoods. Also in the mores of the times, many of the newer projects were high-rises; costs were to be kept low by putting more and more apartments into taller and taller buildings.

Alexander Polikoff, Gautreaux and Institutional Litigation, 64 CHI.-KENT L. REV. 451, 452 (1988). The legality of segregating housing projects by race was upheld in Favors v. Randall, 40 F. Supp. 743, 747-48 (E.D. Pa. 1941).

13347 U.S. 483 (1954).

14 See infra notes $34-78$ and accompanying text.

${ }^{15}$ See, e.g., Robert Gray \& Steven Tursky, Location and Racial/Ethnic Occupancy Patterns for HUD-Subsidized Family Housing in Ten Metropolitan Areas, in HousING DESEGREGATION AND FEDERAL POLICY 235, 249-51 (John M. Goering ed., 1986) [hereinafter HOUSING DESEGREGATION] (concluding that within ten large central cities most projects were located in a relatively small number of nonwhite census tracts and $85 \%$ or more of the occupants of projects located in nonwhite areas were nonwhite).

${ }^{16} 42$ U.S.C. $\$ \S 3601-3619$ (1988) (Title VIII of the Civil Rights Act of 1968).

${ }^{17} I d . \$ \$ 601$.

${ }^{18}$ See, e.g., Gladstone, Realtors v. Village of Bellwood, 441 U.S. 91, 112-15 (1979) (upholding residents' constitutional standing to protest the intentional segregation of their community); Trafficante v. Metropolitan Life Ins. Co., 409 U.S. 205, 210 (1972) (noting the "important benefits from interracial associations"); see also Alexander Polikoff, Sustainable Integration or Inevitable Resegregation?: The Troubling Questions, in HousING DESEGREGATION, supra note 15, at 43, 47 .

19 The FHA covers discrimination in the rental and sale of housing between private individuals, as well as transactions in which the state is directly involved (i.e. any form of subsidized housing). Discrimination in the private sphere is often confused with discrimination in the administration of the public sphere because the results are similar: segregation and lower quality facilities for minorities. The discriminatory practices are also similar in form (either a private actor or a state actor 
tion as a means towards promoting integration. ${ }^{20}$ The "antidiscrimination" goal is explicit in the Act; ${ }^{21}$ the "integration" goal has been read into it, largely through reference to the legislative history. ${ }^{22}$ The cornerstone of the integration argument is the remark by Senator Mondale, the Act's sponsor, that its purpose is to replace the ghettos "by truly integrated and balanced living patterns." 28

It is doubtful that this is a fair reading of the Act. Resurrecting the integration goal from the legislative history, with no explicit mention of this goal in the statute's text, and placing it on a par with the textual anti-discrimination goal, is a questionable hermeneutic enterprise. Moreover, the Supreme Court has indicated that the legislative history is unhelpful in interpreting the $\mathrm{FHA},{ }^{24}$ which was passed in an abbreviated session with no committee reports. ${ }^{25}$

discriminates against a prospective minority buyer or tenant). By placing subsidized housing in nonwhite tracts, the State reinforces and exacerbates patterns of private discrimination. This Comment addresses the remedying of housing discrimination only to the extent that it occurs in federally assisted housing.

${ }^{20}$ See Polikoff, supra note 18 , at 48 . These goals are not entirely independent: the correlation between race and poverty is borne out of discrimination. Since this discrimination in turn affects where people live, housing assistance programs can affect both how and where people live. This broad view of fair housing was incorporated into federal policy with the Housing Act of 1949, the stated aim of which is "a decent home and a suitable living environment for every American family." Housing Act of 1949, Pub. L. No. 81-171, § 2, 63 Stat. 413, 413 (codified as amended at 42 U.S.C. $\$ 1441$ (1988)) (emphasis added).

${ }^{21}$ See 42 U.S.C. \$§ 3604(a), (b), (f)(1)-(3), 3605(a), 3606 (1988).

22 Senator Brooke, a cosponsor of the FHA, expounded on the Act: "Can we state the proposition any more clearly? America's future . . . does not require imposed residential and social integration. . . . It does not require that government interfere with legitimate personal preferences of individuals; it does require that government protect the freedom of individuals to choose where they wish to live." 114 CoNG. REC. 2525 (1968). For a discussion of "race-conscious housing counseling" in light of the Act's legislative history and subsequent commentary, see Polikoff, supra note 18, at 47-50. The legislative history to the Housing and Community Development Act of 1974, Pub. L. No. 93-983, 88 Stat. 633 (1974) (codified in scattered sections of 42 U.S.C.), indicates Congress's goal of developing urban communities through, among other things, "increased neighborhood diversity." H.R. CoNF. REP. NO. 1279, 93d Cong., 2d Sess. 3 (1974), reprinted in 1974 U.S.C.C.A.N. 4273, 4449.

23114 CONG. REC. 3422 (1968). But Senator Mondale also stated:

Obviously, [the Fair Housing Act] is to be read in context with the entire bill, the objective being to eliminate discrimination in the sale or rental of housing .... Without doubt, it means to provide for what is provided in the bill. It means the elimination of discrimination in the sale or rental of housing. That is all it could possibly mean.

Id. at 4975 .

24 See Trafficante v. Metropolitan Life Ins. Co., 409 U.S. 205, 210 (1972).

${ }^{25}$ See Michael F. Potter, Racial Diversity in Residential Communities: Societal Housing 


\section{Current Remedial Doctrine as Structurally Discriminatory}

Subsidized housing is a theater of the ideal world insofar as Congress, the Department of Housing and Urban Development (HUD), and local public housing authorities (PHAs) have the unique opportunity to create and maintain, largely immune from the vicissitudes of a racist private market, communities that reflect the legal interpretation of non-discrimination. ${ }^{26}$ Thus, government determinations of where to place and permit subsidized housing should be subjected to excruciating examination under the theory that site selection is the state's demonstration of the way the private market should function were it entirely consistent with the FHA and equal protection. ${ }^{27}$

Patterns and a Proposal for a "Racial Inclusionary Ordinance," 63 S. CAL. L. REV. 1151, 1224 (1990); Rodney A. Smolla, Integration Maintenance: The Unconstitutionality of Benign Programs that Discourage Black Entry to Prevent White Flight, 1981 DUKE L.J. 891, 910-11.

${ }^{26}$ See John Yinger, On the Possibility of Achieving Racial Integration Through Subsidized Housing, in HOUSING DESEGREGATION, supra note 15, at 290, 302 (finding that " $[t]$ he starting point for any site selection procedure is the principle that, all else equal, subsidized housing should be placed in neighborhoods where low-income households would be most likely to live without restrictive zoning or racial discrimination"). Of course, the administration of subsidized housing reflects current public policy, but that policy has leeway only to the extent that it remains within the bounds of the legal doctrine. For example, levels of funding and physical design are primarily policy determinations, but the administration of the funding must not violate constitutional prohibitions against discrimination.

The legal meaning of "discrimination" is still evolving. It was not until 1954, nearly a century after the Equal Protection Clause was added to the Constitution, that the Court recognized that segregation based on race with "equal" accommodations violated the Fourteenth Amendment. See Brown v. Board of Educ., 397 U.S. 483 (1954). Statutory discrimination against women was not identified as a constitutional violation until 1971. Compare Reed v. Reed, 404 U.S. 71 (1971) (invalidating an Idaho law mandating that "[o]f several persons ... equally entitled to administer [a decedent's estate], males must be preferred to females") with Bradwell v. Illinois, 83 U.S. (16 Wall.) 130 (1872) (upholding state bar association's denial of admission to women). Gender-based discrimination in places of public accommodation remains legal under Titles II and III of the Civil Rights Act of 1964, Pub. L. No. 88-352, 78 Stat. $245,245-46$ (codified at 42 U.S.C. $\$ \$ 2000 \mathrm{a}$ to $2000 \mathrm{~b}-3,2000 \mathrm{~b}$ to $2000 \mathrm{~b}-3$ (1988)). See DeCrow v. Hotel Syracuse Corp., 288 F. Supp. 530, 531-32 (N.D.N.Y. 1968) (holding that Title II does not prohibit private hotel from maintaining a policy of refusing to serve "an unescorted woman" at a restaurant bar). Only recently has the law recognized that even subtle forms of discriminatory behavior are equally objectionable and injurious. See, e.g., McDonnell Douglas Corp. v. Green, 411 U.S. 792, 801 (1973) (stating that "Title VII [Equal Employment Opportunities] tolerates no racial discrimination, subtle or otherwise"). Congress's current view of what constitutes discriminatory behavior is codified in Chapter 21 (Civil Rights) of Title 42 (Public Health and Welfare) of the United States Code.

${ }^{27}$ The branch of equal protection doctrine embraced by this Comment's analysis 
Martin Luther King, Jr., W.E.B. DuBois, and many other civil rights leaders have supported a program of integration based on the "contact hypothesis" view that integration leads to greater authentic understanding among the races and a corresponding waning of antagonism based on racial differences. ${ }^{28}$ For a long time, civil rights advocates and the courts interpreted this approach to racial harmony to mean that integration was an end in itself, thus assuming that absent discrimination, the social, political, and economic orders would be entirely integrated. ${ }^{29}$

Integrating subsidized housing is a valid and necessary means under the FHA to eradicate past discrimination in the public and private housing markets, and this approach to civil rights reform has achieved deeply significant progress towards racial equality. Where, however, the goal of integration is pursued to deny legitimacy to

is the prohibition against stigma. The Supreme Court has repeatedly recognized that the Equal Protection Clause of the Fourteenth Amendment invalidates state action employing a race-based classification if the scheme implicates a hierarchical view of race in which one or more races are subordinated. See, e.g., Strauder v. West Virginia, 100 U.S. 303, 308 (1880) (striking down state statute rendering only white males eligible for jury service based on Fourteenth Amendment right to be "exempt[] from legal discrimination implying inferiority in civil society"); Brown v. Board of Educ., 397 U.S. 483, 494-95 (1954) (declaring that "[s]eparate educational facilities are inherently unequal"); Loving v. Virginia, 388 U.S. 1, 11-12 (1967) (finding unconstitutional a state statute prohibiting interracial marriage because it was based on notions of white supremacy and the "integrity of the white race"); Regents of the Univ. of Cal. v. Bakke, 438 U.S. 265, 357-58 (1978) (Brennan, White, Marshall, Blackmun, J., concurring in part and dissenting in part) (" $[R]$ acial classifications that stigmatizebecause they are drawn on the presumption that one race is inferior to another or because they put the weight of government behind racial hatred and separatism-are invalid without more." (citations omitted)); see also Roberts v. United States Jaycees, 468 U.S. 609, 625 (1984) (striking down on stigma grounds, among others, the exclusion of women from a prominent community civic organization).

${ }^{28}$ See Potter, supra note 25, at 1182; see also BLACR PROTEST ThOUGHT IN THE TwENTIETH CENTURY 67-72, 291-306 (August Meier et al. eds., 1965) (excerpting writings of King and DuBois); DANIEL W. WYNN, THE BLACK PROTEST MOVEMENT 209-12 (1974) (discussing the integrationist agenda).

${ }^{29}$ See, e.g., Green v. County Sch. Bd., 391 U.S. 430, $441-42$ (1968) (striking down a "freedom of choice" school desegregation plan as inadequately complying with Brown II, see Brown v. Board of Educ., 349 U.S. 294 (1955), and ordering the school board affirmatively to integrate the district); United States v. Jefferson County Bd. of Educ., 372 F.2d 836, 894-96 (5th Cir. 1966) (holding that the Constitution compels formerly de jure segregated public school systems based on dual attendance zones to shift to unitary non-racial systems). See generally Ankur J. Goel, Maintaining Integration Against Minority Interests: An Anti-Subjugation Theory for Equality In Housing, 22 URB. LAW. 369, 385-402 (1990) (discussing integration as the traditional civil rights movement's driving vision); Ankur J. Goel et al., Comment, Black Neighborhoods Becoming Black Cities: Group Empowerment, Local Control and the Implications of Being Darker Than Brown, 23 HARV. C.R.-C.L. L. REV. 415, 427-31 (1988) (same). 
nonwhite community, the anti-discrimination goal of the FHA and equal protection are violated. The project of exploring alternatives to an obsessive remedial focus on integration should not invoke a terrain defined by conservative politics, but instead should take the form of a more sensitive approach to addressing nonwhite concerns. ${ }^{30}$ If the subsidized housing stage is to be shared by both "anti-discrimination" and "integration," the second goal must yield the spotlight to the first should they conflict.

This Comment argues that judicial remedies that force integration in subsidized housing fail to account for the right of nonwhite tenants to choose not to integrate. ${ }^{31}$ Forced integration in subsidized housing presumes that in a society free from discrimination nonwhites will choose to live dispersed among whites. ${ }^{32}$ This belief itself is discriminatory because it denies legitimacy to nonwhite community, implying that the only proper residential

${ }^{30}$ See generally Derrick A. Bell, Jr., Serving Two Masters: Integration Ideals and Client Interests in School Desegregation Litigation, 85 YALE L.J. 470, 471 (1976) (noting that in the school desegregation context "[t]here is increasing opposition to desegregation at both local and national levels (not all of which can now be simply condemned as 'racist')"). Eradicating discrimination in assisted housing does not necessarily entail desegregation, but rather "nonsegregation." See infra notes 133-185 and accompanying text.

${ }^{31}$ See generally Henry W. McGee, Jr., Afro-American Resistance to Gentrification and the Demise of Integrationist Ideology in the United States, 23 URB. LAW. 25, 28-29, 39-41 (1991) (arguing that contrary to the widespread support of integration when that agenda "was at its zenith in the heady days of the Civil Rights movement," today "many blacks no longer embrace an arguably dated integrationist ideology").

W.E.B. DuBois, while a proponent of integration, also counseled:

The experience in the United States has been that usually when there is racial segregation, there is also racial discrimination. But the two things do not necessarily go together, and there should never be an opposition to segregation pure and simple unless that segregation does involve discrimination. ... [T] [Tere [is] no objection to colored people living beside colored people if the surroundings and treatment involve no discrimination, if the streets are well lighted, if there is water, sewerage and police protection, and if anybody of any color who wishes, can live in that neighborhood. . . . But never in the world should our fight be against association with ourselves because by that very token we give up the whole argument that we are worth associating with.

W.E.B. DuBois, Postscript, THE CrIsIs, Jan. 1934, at 20.

${ }^{32}$ Housing subsidies are unlike other income-related subsidies in that they have been administered to achieve a goal independent of their primary purpose. For example, Medicare and Medicaid enable the purchasing of better health care, food stamps enable the purchasing of more or better food, and welfare is a direct income subsidy. But while housing assistance enables the tenant to "purchase" better housing, it is also used as a vehicle to accomplish the separate goal of integration. 
pattern is one where a majority white community prevails over a submerged nonwhite minority. ${ }^{38}$

The judicially enforced belief that integration, no matter how small the scale on which it is implemented, will eradicate discrimination carries with it racist assumptions about assimilating nonwhites by diluting nonwhite identity through dispersal. This belief assumes that absent pervasive discrimination nonwhites would necessarily choose to live amidst the white majority rather than live among others with whom they share common heritage, values, beliefs, and culture, as many ethnic whites do (e.g., Italians, Jews).

Since Title VIII bans both overt and subtle racism, any remedial measure that contains traces of even subtle racism is invalid. This Comment tracks and reveals these subtle-yet no less invidious and harmful-racist assumptions as they are played out in the judicial treatment of involuntary and voluntary remedies to past discrimination in the administration of federally assisted housing programs.

Section I of this Comment discusses involuntary, or courtimposed, desegregation orders for municipalities found to have maintained a segregated system of subsidized housing by locating housing projects primarily in nonwhite residential areas, or by segregating tenants. This is the most basic manifestation of the

${ }^{33}$ Cf. Goel, supra note 29, at 391-92. Goel argues that the guiding principle behind a non-discriminatory integration-promoting administration of the Fair Housing Act should be "anti-subjugation." "Anti-subjugation," according to Goel, "holds that "it is inappropriate for certain groups in society to have subordinated status because of their lack of power in society as a whole." Id. at 395 (quoting Ruth Colker, Anti-Subordination Above All: Sex, Race, and Equal Protection, 61 N.Y.U. L. REv. 1003,1007 (1986)).

Goel's analysis of integration maintenance programs illustrates the necessity of recognizing the legitimacy of minority choice:

Some integration maintenance programs stigmatize those who civil rights legislation was intended to benefit. In the focus on achieving integration, some also cast aside the more important goal of improving housing conditions for members of previously oppressed groups. Finally, some integration maintenance programs show a disregard for the independent pluralistic and political values minority groups can gain by choosing not to integrate.

Id. at 415 .

Under this "anti-subjugation" analysis, "demand alteration" measures seeking to encourage white entry into nonwhite communities or steering nonwhites away from white neighborhoods are unacceptable, as are ceiling quotas. But two-way "benign steering" measures, employing counseling and financial incentives, as well as "equity insurance" plans to compensate private homeowners for declines in their property values resulting from nonwhite entrance into white neighborhoods, would be permitted. 
remedial structure that privileges integration over anti-discrimination. Under traditional civil rights analysis wide-scale forced integration would be the cure for these broad-based discriminatory policies. Even accepting this premise, the courts have been halting and considerably restrained in ordering integration. Consequently, the tentative spurts of subsidized housing integration have resulted in tokenism and devaluation of nonwhite community.

Section II discusses the courts' pursuit of integration at the expense of anti-discrimination, specifically focusing on their treatment of nonwhite ceiling quotas within projects. This line of cases has carved out a rule that permits such measures if the white community's interest in preventing "white flight" from the areas surrounding the projects is defined broadly. This rule sacrifices the anti-discrimination goal and is highly stigmatizing. Ceiling quotas on nonwhite tenants marginalize nonwhites by implying that the nonwhite population in a "valid community" is always restricted to a minority proportion. This Section argues that even if "white flight" were a sociologically cognizable reaction to nonwhite population dominance, the courts have no business lending legitimacy to the racist fears of whites by constructing myopic legal rules around them.

Section III considers the "integration versus anti-discrimination" calculus in the analysis of site selection for new projects. Regulations promulgated by HUD that prohibit building in areas of "minority concentration" privilege integration to the detriment of critical housing needs within existing nonwhite communities. Although there is a strong presumption in light of history that placing projects in nonwhite areas is motivated by an effort to relegate poor nonwhites (and nonwhites generally) to the geographic and social margins, these regulations, consistent with prior. jurisprudence, effectively dismiss the desire to cultivate nonwhite community as irrelevant. This practice probably reflects the remedial process's inability to accord value to minority voices rather than an active negation of nonwhite choice. Fortunately, the courts have shown a tendency to look beyond traditional remedial analysis: recognizing that nonwhites may desire better housing more than integrated housing, they have generally favored the building of new subsidized housing over strict adherence to the regulations. 


\section{INVOLUNTARY REMEDIES: JUDICIAL RESTRAINT IN SITE INTEGRATION}

\section{A. The Gautreaux Case}

In 1966, a group of nonwhite public housing tenants filed suit against the Chicago Housing Authority (CHA) and HUD alleging that, in violation of the Fifth Amendment and Title VI, nearly all of the family public housing sites selected by CHA between 1950 and 1965 were located "within the areas known as the Negro Ghetto" in order to "avoid the placement of Negro families in white neighborhoods." 34 The uncontradicted evidence showed that the Chicago system was entirely segregated, "with four overwhelmingly white projects located in white neighborhoods and with $991 / 2 \%$ of the remaining family units located in Negro neighborhoods and $99 \%$ of those units occupied by Negro tenants." 35 The district court found that almost $100 \%$ of potential project sites in white neighborhoods were vetoed compared with $10 \%$ of potential sites in nonwhite neighborhoods. ${ }^{36}$

Even though the violation appeared to be confined to the city limits of Chicago, the Supreme Court upheld a comprehensive interdistrict remedy that extended throughout metropolitan Chicago and into the surrounding suburbs. Justice Stewart distinguished the then-recent school desegregation case, Milliken $v$. Bradley, ${ }^{37}$ which held that there could not be an interdistrict remedy absent an interdistrict violation. He urged flexibility in constructing equitable relief since HUD had violated the Constitution, ${ }^{38}$ the $\mathrm{CHA}$ and

${ }^{34}$ Gautreaux v. Chicago Hous. Auth., 265 F. Supp. 582 (N.D. Ill. 1967); Gautreaux v. Romney, 332 F. Supp. 366 (N.D. Ill. 1971), rev'd, 457 F.2d 124 (7th Gir. 1972).

Elements of this litigation were still pending as recently as 1990. See, e.g., Gautreaux v. Kemp, 132 F.R.D. 193 (N.D. Ill. 1990) (denying petitions to enjoin construction of 101 townhouses to be built on 11 scattered sites, based on unsubstantiated assertion that the neighborhood was already $99 \%$ black). The Gautreaux litigation was purportedly terminated in 1981 when CHA, HUD, and the plaintiff class entered into a consent decree. See Gautreaux v. Pierce, 690 F.2d 616, 621-24 (7th Cir. 1982).

35 Hills v. Gautreaux, 425 U.S. 284, 288 (1976). In July 1968 the CHA was comprised of 54 family housing projects with 30,848 units. See id. at 288 n.5.

${ }^{36}$ See Gautreaux v. Chicago Hous. Auth., 296 F. Supp. 907, 912 (N.D. Ill. 1969). Judge Austin held that statistics by themselves were sufficient to prove intent, reasoning that "[n]o criterion, other than race, [could] plausibly explain" the pattern of site selection. Id.

37418 U.S. 717 (1974).

${ }^{38}$ See Gautreaux, 425 U.S. at 297. 
HUD had powers extending beyond Chicago city limits, ${ }^{39}$ and the operation of this system had "significant segregative effects in the suburbs. "40 Using HUD's own guidelines, ${ }^{41}$ Justice Stewart concluded that "[t]he relevant geographic area for purposes of the respondents' housing options is the Chicago housing market, not the Chicago city limits." 42

Chicago's politicians proved their unyielding stamina in resisting the implementation of the Gautreaux metropolitan order against CHA. Between 1969, when the district court had sought only to implement a remedy within Chicago city limits, and 1974 no new public housing was built in Chicago. The Chicago City Council vetoed every CHA proposal for a new site. ${ }^{43}$ Judge Austin enjoined their veto power in 1972, but the injunction did not take effect until the Supreme Court denied certiorari in $1974 . .^{44}$ Public opposition provided the next set of barriers. Between 1974 and 1979 only 117 new units were constructed. ${ }^{45}$ In 1979 Mayor Jane Byrne pledged her support to the scattered-site program on the condition that the agreed-upon ratio of units built in white areas to units built in nonwhite areas be reduced from three-to-one to oneto-one. ${ }^{46}$ New construction then proceeded so slowly that the CHA was placed in receivership in May $1987 .^{47}$

The portion of the order directed at HUD was implemented in a much more effective manner through development of the "Gautreaux Demonstration." ${ }^{48}$ This Section 8 program $^{49}$ used a

${ }^{39}$ See id. at 298-300.

40 Id. at 294.

${ }^{41}$ Id. at 299 (quoting DEPARTMENT OF Hous. \& URBAN DEV., FHA TECHNIQUES OF HOUSING MARKET ANALYSIS 12 (1970), which states that the housing market area "usually extends beyond the city limits" and in larger markets "may extend into several adjoining counties").

42 Id. at 299.

${ }^{43}$ See Polikoff, supra note 12 , at 459.

44 See Gautreaux v. Chicago Hous. Auth., 342 F. Supp. 827 (N.D. Ill. 1972), aff'd, 480 F.2d 210 (7th Cir. 1973), cert. denied, 414 U.S. 1144 (1974).

45 See Polikoff, supra note 12, at 459-60.

${ }^{46}$ See id. at 460 .

${ }^{47}$ See Adam M. Shayne, Accelerating Integration: Effective Remedies in Public Housing Discrimination Suits, 23 U. MICH. J.L. REF. 375, 387 (1990).

48 See id. at 385 .

49 "Section 8 " refers to the provision of the Housing and Community Development Act of 1974, Pub. L. No. 93-383, 88 Stat. 633 (codified at 42 U.S.C. $\$ 1437 f$ (1988)), that created three new housing assistance programs for low-income families: Existing Housing, New Construction, and Substantial Rehabilitation. Section 8 "Existing Housing" is a demand-subsidy program that provides participating families with "certificates" or "vouchers" with which they can pay rent to private landlords. 
housing assistance payment approach to provide two to three hundred units of subsidized housing a year to the Gautreaux plaintiffs; ${ }^{50}$ it resulted in aid to 3500 families (over 10,000 tenants) and the relocation of many of them to the suburbs. ${ }^{51}$

\section{B. Gautreaux's Legacy}

The Supreme Court's sweeping remedy in Gautreaux seemed to open the doors for voluntary implementation of programs like the Gautreaux Demonstration on a nationwide scale. HUD and local PHAs declined the invitation. At the very least, the decision gave the green light to private plaintiffs and the U.S. Attorney to bring suits against local PHAs to remedy segregative site selection through involuntary metropolitan desegregation orders. In the few cases litigating claims of discriminatory site selection, the courts have designed remedies much less extensive than permitted by the Supreme Court in Gautreaux. The orders, which are discussed in this Section, are examples of excessive judicial restraint.

When implemented on a large scale, as with the Gautreaux Demonstration, "scattered site" housing probably achieves some discrimination reduction by means of integration. ${ }^{52}$ The very limited scope of the remedies ordered, however, even in cases where the intensity of the violation ranks with that in Gautreaux, creates a perfunctory judicial gesture towards integration that achieves little more than tokenism. ${ }^{53}$ The practical result is that

The units must meet federal minimum quality standards, see infra note 152 , and rent for less than a market-indexed ceiling. Under Section 8 "New Construction," HUD guarantees private developers of new housing projects that it will subsidize rental payments provided that some or all of the units are made available to low-income households. "Substantial Rehabilitation" operates similarly with respect to owners who agree to renovate existing structures. See generally GENERAI ACCOUNTING OFFICE, SECTION 8 SUBSIDIZED HOUSING-SOME OBSERVATIONS ON ITS HIGH RENTS, COSTS AND INEQUITIES 1-7 (1980).

${ }^{50}$ See Shayne, supra note 47 , at 385.

51 See id.

52 About half of the 8500 families relocated under the Gautreaux Demonstration moved to the suburbs of Chicago. According to a HUD study, $84 \%$ felt that the quality of their lives had improved. See DIVISION OF POLICY STUDIES, DEP'T OF HOUS. \& URB. Dev., The GaUtreaux Housing Demonstration: AN Evaluation of ITS IMPACT ON PARTIGIPATING HOUSEHOLDS li (1979), cited in Polikoff, supra note 12, at 474.

53 The impact on families can be quite severe. Two commentators noted the costs of limited measures of integration:

The social isolation of being greatly outnumbered as a minority resident in a predominantly white suburb could only aggravate the hurt of any racially 
a limited number of participants gain access to the higher-quality municipal services of the suburbs, but the bulk of assisted families remains concentrated in segregated areas and facilities with the judicial role exhausted. Thus, the violation remains substantially without redress, despite the court's having waved its remedial magic wand.

\section{United States v. Yonkers Board of Education ${ }^{54}$}

The Yonkers case provides the most striking recent example of a blatant and extensive violation of the Fair Housing Act and the Fourteenth Amendment redressed with a small-scale remedy. Yonkers, New York, is substantially segregated. The bulk of the nonwhite population is confined to the southwest portion of the city. Ninety-seven percent of Yonkers's subsidized housing is located in southwest Yonkers. ${ }^{55}$ None of the City's twenty-seven subsidized housing projects for families are located in the overwhelmingly white neighborhoods in the east and northwest. ${ }^{56}$ The district court found that the city had engaged in over thirty years of intentional discrimination, ${ }^{57}$ placing the predominantly nonwhite

motivated harassment experienced there and would certainly lessen the willingness of minority groups to move to integrate. The personal and social costs of [limited] integration may be too high for minorities to bear willingly.

Wilhelmina A. Leigh \& James D. McGhee, A Minority Perspective on Residential Racial Integration, in HOUSING DESEGREGATION, supra note 15, at $31,37$.

${ }^{54} 624$ F. Supp. 1276 (S.D.N.Y. 1985), affd, 837 F.2d 1181 (2d Cir. 1987), cert. denied, 486 U.S. 1055 (1988).

${ }^{55}$ See id. at 1348.

56 See id. at 1364. The only measure in the Yonkers Housing Assistance Plan "that offered any significant chance of dispersing at least some subsidized housing for families into the overwhelmingly white neighborhoods of East and Northwest Yonkers" was a 1974-75 proposal for 100 Section 8 Existing certificates, see infra note 152 (defining the "Section 8 Existing" program), split 50-50 between families and senior citizens. See Yonkers, 624 F. Supp. at 1343.

57 The court found that "the desire to preserve existing patterns of segregation has been a significant factor in the sustained community opposition to subsidized housing in ... overwhelmingly white areas of the City." Yonkers, 624 F. Supp. at 1371. The court was not greatly concerned with uncovering discriminatory purpose; to this end Judge Sand did not require proof that decisions on site selection were based wholly on race: "[S]uch findings could rarely, if ever, be made." Id; see also Village of Arlington Heights v. Metropolitan Hous. Dev. Corp., 429 U.S. 252, 266 (1977) (stating that " [d]etermining whether invidious discriminatory purpose was a motivating factor demands a sensitive inquiry into such circumstantial and direct evidence of intent as may be available"). Judge Sand noted that, from the perspective of theory, the case presented an unusually difficult challenge for pegging intent because the violation occurred over a 30 -year span by a changing group of city 
family projects in southwest Yonkers and locating the generally white housing projects for the elderly in white areas. ${ }^{58}$

Given the scale of the violation, the remedial order was remarkably restrained. The consent decree approved by the district court provided for a core of 200 low- and very-low-income townhouse-style units to be built immediately in the white areas of Yonkers and for a less definite agreement to make "good faith efforts" to foster the private development of another 600 units of "affordable" housing over the next three years. ${ }^{59}$ The Second Circuit, in denying Yonkers's challenge to the remedy, recognized that " $[t]$ he number of units, 200, was hardly excessive in light of the City's agreement with HUD [(the consent decree describing the extent of the violation)] and the existing concentration of 6,566 units of housing, or $96.6 \%$ of all of its subsidized housing, in Southwest. ${ }^{200}$ If the defect of Yonkers's system lies in its segregation, locating a mere ten percent of its subsidized housing in white areas hardly embarks down the road to meaningful integration. ${ }^{61}$

\section{United States v. City of Parma ${ }^{62}$}

The district court in City of Parma found that Parma, the largest suburb of Cleveland, had maintained a "long-standing policy and practice of excluding black persons from residing in Parma in any substantial numbers. ${ }^{\text {63 }}$ Parma violated the Fair Housing Act by

officials. See Yonkers, 624 F. Supp. at 1369. He indicated, however, that "when the segregative effect of an action is extreme, or when there is a series of actions having a consistently segregative effect, the inference is stronger that the effect of the actions is intended. Id.

58 Placement of elderly housing projects, "which, unlike subsidized housing for families, tended to be heavily white," provoked far less opposition in the white areas of Yonkers. See Yonkers, 624 F. Supp. at 1371.

${ }^{59}$ City of Yonkers v. United States, 487 U.S. 1251, 1252 (1988) (Marshall, J., concurring in relevant part).

${ }^{60}$ United States v. Yonkers Bd. of Educ., 837 F.2d 1181, 1237 (2d Cir. 1987) (emphasis added), cert. denied, 486 U.S. 1055 (1988).

61 A limited remedy was also imposed by the court in Resident Advisory Board v. Rizzo, 564 F.2d 126 (3d Cir. 1977). The court was presented with evidence that discrimination by the Philadelphia PHA and HUD that segregated the Whitman Urban Renewal Area ran throughout the interrelated projects of the Philadelphia system. The lower court ordered systemwide desegregation, but the Third Circuit confined the remedy to the proposed Whitman project. See id. at 152.

62494 F. Supp. 1049 (N.D. Ohio), remedial order, 504 F. Supp. 913 (N.D. Ohio 1980), affd in part, rev'd in part, 661 F.2d 562 (6th Cir. 1981).

${ }^{63}$ City of Parma, 504 F. Supp. at 915. Parma had a population of 100,216 of whom 50 residents were African-American. See City of Parma, 661 F.2d at 566. The trial court found that " $[t]$ he proposition that the Cleveland metropolitan area and 
its "adamant and longstanding opposition to any form of public or low-income housing," specifically the denial of a building permit for a low-income housing development, the passage of a thirty-five-foot residential height restriction ordinance, and the passage of an ordinance requiring voter approval for low-income housing. ${ }^{64}$

Among other remedies, ${ }^{65}$ the court required Parma to build 133 units of low-income housing per year, and it appointed a special master to supervise the program. ${ }^{66}$ Given HUD's determination that Parma's low-income housing need was 2669 units and that the city currently had none, the order was a measured effort at relief in light of the court's duty "to eliminate, to the extent possible, the discriminatory effects of Parma's [past] actions, ${ }^{, 67}$ especially where Congress expressly authorized such sweeping relief. ${ }^{68}$

The district court explicity recognized the likelihood of political impediments to implementing the remedy, and for this reason set a specific number of units and appointed a special master to

Parma became racially segregated solely as a result of associational preferences and economics, and not because of racial discrimination, is refuted overwhelmingly by the evidence in this case." City of Parma, 494 F. Supp. at 1057.

${ }^{64}$ See City of Parma, 504 F. Supp. at 915. The court found all these actions motivated by "a racially discriminatory and exclusionary intent and had foreseeable segregative effects." Id.

65 The district court's willingness to fashion an extensive and highly specific remedy highlighted the severity of the violation. One aspect of the remedial order required Parma to advertise itself as an "open community" where "all persons are welcome" and to proclaim that "discriminatory practices which have characterized Parma in the past no longer reflect the attitude of the City and its citizens." Id. Another required all Parma city officials and employees to undergo a mandatory "fair housing educational program." Id. at 918.

${ }^{66}$ See id. at 923.

${ }^{67}$ Id. at 916.

68 See, e.g., 42 U.S.C. $\$ 3613(c)(1)$ (1988) (establishing that in a suit by a private person injunctive relief includes ordering affirmative action); id. $\$ 3614$ (d)(1)(A) (establishing that in a suit by the Attorney General, "the court ... may award such preventative relief, including a permanent or temporary injunction, restraining order, or other order against the person responsible for a violation of this subchapter"); see also Park View Heights Corp. v. City of Black Jack, 605 F.2d 1033, 1040 (8th Cir. 1979) (noting that a remedial provision of FHA requires fashioning relief to the extent that it will eliminate the discriminatory effects of the violative action). The Parma district court reasoned that

the magnitude of Parma's liability has necessitated a remedy which addresses the numerous illegal actions by the Defendant City. The magnitude of the wrong has dictated the magnitude of the remedy, which is, necessarily, broader than remedies in prior housing cases which involved [only] a single discriminatory ordinance and/or the development of a single low-income housing project.

City of Parma, 504 F. Supp. at 924. 
monitor the order. ${ }^{69}$ On appeal, the Sixth Circuit affirmed the district court's findings of fact ${ }^{70}$ and upheld all aspects of the remedy except the requirement that a specific number of units be built and the appointment of a special master. ${ }^{71}$

The circuit court gave surprisingly little reason for reversing the setting of a specific number, noting only that "we believe that no particular number should be required at this time, but that a goal of meeting the need for such housing within a reasonable time should be established by the [fair housing] committee. ${ }^{n 72}$ The court applied an "exceeding its authority" yardstick for measuring the appropriateness of the remedy. ${ }^{73}$ Given the facts of the case, the trial court's equitable order should have been found well within this standard. Even if the "housing need" as determined by HUD were $50 \%$ too high, the 133 annual units would only satisfy ten percent of Parma's low-income housing deficit. ${ }^{74}$ At this level, it would still have taken ten years to counter the quantitative effects of Parma's discrimination. Likewise, the appointment of a special master has precedent in the Gautreaux case, ${ }^{75}$ and was subsequent-

${ }^{69}$ See City of Parma, 504 F. Supp. at 924 n.17 (recognizing the obstacles encountered in Gautreaux); see also id. at 926 (noting that " $[t]$ he ultimate responsibility for the success of the remedial plan in this litigation lies with the City of Parma").

${ }^{70}$ See United States v. City of Parma, 661 F.2d 562, 570 (6th Cir. 1981).

71 See id. at 577-78. A district court order requiring a specific number of assisted housing units to be built was also at issue in Smith v. Town of Clarkton, 682 F.2d 1055 (4th Cir. 1982). At the time of the case, Clarkton was an unincorporated municipality of 664 people, $88 \%$ white, in one of the poorest counties in North Carolina. See id. at 1060 . Forty percent of all families qualified for federally subsidized low-income housing. See $i d$. at 1061 . The per-capita income was $\$ 4,261$ (African-Americans average $\$ 1,722$ ). See id. The district court found that the Town Commissioners/defendants, in violating the FHA, had bowed to racially motivated public pressure by ordering the town's withdrawal from a multi-municipality housing project, thereby blocking the construction of 50 low-income public housing units in Clarkton. See id. at 1063 . The lower court remedy required the town itself (and alternatively, the individual defendants) to construct the 50 units within the town limits whether or not it could obtain federal financing. See id. at 1067. The circuit court modified this part of the order and construed it as "requiring the defendants to take each and every step, short of directly funding actual construction, necessary to facilitate the development of low-rent housing in Clarkton." Id. at 1070. The court reasoned that Clarkton's lack of financial resources made it impractical to undertake the construction on its own. See id. at 1069. Further, the Circuit Court felt that the defendants themselves were "people of good will" but that they were victims of "aggressively mounted public opinion pressure" by "[c]itizens of ill will." Id. at 1068.

72 City of Parma, 661 F.2d at 578.

73 See id. at 576.

74 See City of Parma, 504 F. Supp. at 923 (accepting HUD's determination that Parma's low-income housing need was 2669 units).

${ }^{75}$ See Gautreaux v. Chicago Hous. Auth., 384 F. Supp. 37, 38 (N.D. Ill. 1974); 
ly ordered and upheld in the remedy to East Texas's segregated public housing system under similar circumstances. ${ }^{76}$ The Sixth Circuit's aversion to mandating and enforcing the construction of a specific number of units infuses fatal vagueness into the remedy and invites its frustration. ${ }^{77}$

The preceding cases illustrate two points. First, if housing integration is considered by the FHA to be an end in itself, the postGautreaux courts have been extremely slow to implement it on a broad scale, despite being confronted with egregious violations of the FHA and the Fourteenth Amendment. Second, even assuming that large-scale integration could be freed from racist conceptions of what constitutes valid community in order to render it a legitimate goal of the FHA, the token scale of court-ordered integration relative to the magnitude of the violations undermines the assumption. Scattered-site housing in minute quantities is an inefficacious sprinkle of a cure on a massive disease. The idea that even the most minimal dose of integration will benefit nonwhite tenants is inherently discriminatory: small infusions of mostly nonwhite assisted persons into white areas hardly eradicates discrimination where the bulk of assisted persons remains in segregated housing and the few relocated to scattered-site clusters are merely remarginalized by virtue of their systemic isolation. Essentially, the courts in the cases discussed above seem constrained to order integration, no matter how narrow the scope, because they perceive no judicially manageable alternative on the remedial horizon. ${ }^{78}$

mandamus denied, Chicago Hous. Auth. v. Austin, 511 F.2d 82, 86 (7th Cir. 1975).

${ }^{76}$ In the East Texas segregation case, the district court appointed a special master “to monitor and report on HUD's desegregation efforts, to study the operation of the publicly funded housing programs in East Texas, and to recommend further action that might be taken as part of a comprehensive remedial decree." Young v. Pierce, 640 F. Supp. 1476, 1477 (E.D. Tex. 1986), vacated and remanded on other grounds, 822 F.2d 1368 (5th Cir. 1987) (remanding to clarify the scope of the special master's powers).

${ }^{77}$ See A. Dan Tarlock, Remedying the Irremediable: The Lessons of Gautreaux, 64 CHI.-KENT L. REV. 573, 579, 582 (1988) ("There has been a tendency for courts to trim the right to fit the remedy, thus diluting the force of the underlying right .... Political resistance to racial integration is a given; almost every remedy will have to be enforced in the face of hostile opposition."); see also Gene B. Sperling, Judicial Right Declaration and Entrenched Discrimination, 94 YALE L.J. 1741, 1742 (1985) (arguing that "judges should conceptually and procedurally bifurcate their determination of right and remedy" and formulate remedies so that disputes about remedies do not work to narrow individual rights).

${ }^{78}$ Cf. Lani Guinier, The Triumph of Tokenism: The Voting Rights Act and the Theory 


\section{VOluntaRY REMEdiES: THE LEgAL RATIFICATION OF "TIPPING"}

"[W]e know of hardly a more suppressive move that governments can take in this society, than to control where we can live. Would any other people in this Country even be thought of as fit subjects for such policies? And, would any other People not raise holy hell at the very thought that they should be shunted around from area to area, in the interests of satisfying white fear that whites will flee an area (or decline to move in)? "79 $^{\text {79 }}$

Consistent with judicial approval of limited forced integration as the only remedy to discrimination in subsidized housing and the resulting devaluation of the notion of nonwhite community as a legitimate entity has been the reification and validation of the racist dynamic known as "white flight" or "tipping" in subsidized housing jurisprudence. "Tipping" has been defined as the theory that "every community has a 'tipping point,' a specifiable numerical ratio of blacks [and other nonwhite groups] to whites beyond which the rate of white migration out of a transitional area will increase rapidly, eventually yielding a predominantly black community. "80 The existence of a "tipping point" is the asserted justification for using ceiling quotas to contain the proportion of nonwhite residents in a project, which prevents the "white flight" that would ensue if the nonwhite population grew to excess.

The proposition is theoretically unsound. It draws upon an anglocentric binary view of ethnicity with whites at one pole and everyone of color (e.g., African-Americans, Hispanics, AsianAmericans, Native Americans ${ }^{81}$ ) at the other. The courts that have considered "tipping" have never challenged the polarity of this view.

of Black Electoral Success, 89 MICH. L. REV. 1077, 1091-101 (1991) (arguing that the judiciary's search for a core value in the 1965 Voting Rights Act has resulted in a narrow focus on vindicating the consistent election of African-American officials to the detriment of the original goals of the Act and the civil rights movement: voter participation, effective representation, and policy responsiveness).

${ }^{79} \mathrm{John}$ M. Goering, Introduction to Housing DESEGREGATION, supra note 15 , at 15 n.3 (quoting letter written to the NAACP).

${ }^{80}$ Note, Tipping the Scales of Justice: A Race-Conscious Remedy for Neighborhood Transition, 90 YALE L.J. 377, 379 (1980); see also Derrick A. Bell, Jr., Application of the "Tipping Point" Principle to Law Faculty Hiring Policies, 10 NovA L. REv. 319, 324 (1986) (finding that "[c]ourts have approved the policy on the grounds that it furthers the national goal of integrated housing").

${ }^{81}$ The terms themselves are ethnocentric amalgamations of widely differing cultures. 
Social science support for the actual existence of "tipping" is, at best, mixed. ${ }^{82}$ The most that can be asserted is that white flight may occur to some degree. Justifying minority ceiling quotas in the face of such amorphous information seems irrational. The stigmatization of nonwhites by the acceptance of this proposition is severe. ${ }^{83}$ Judicial ratification of a concept that is so obviously generated by racist fears cannot be tolerated under equal protection. $^{84}$

82 One scholar finds white flight discernable only insofar as it is a continuous outmigration of white residents from the cities to the suburbs. See John M. Goering, Neighborhood Tipping and Racial Transition: A Review of Social Science Evidence, 44 AM. INST. PLAN. J. 68, 70 (1978). He concludes that within specific urban or suburban neighborhoods there is "no social science evidence that supports the existence of a single, universally applicable tipping point which can explain and predict the point at which neighborhoods will irreversibly change from white to nonwhite." Id. at 69. In the school desegregation context, one study found that "from 1967 to 1972, no statistically significant relationship between racial desegregation and loss of white students could be demonstrated, whether in the North or the South, in large or small urban districts." Thomas F. Pettigrew \& Robert L. Green, Urban Desegregation and White Flight: A Response to Coleman, in NEW PERSPECTIVES ON SCHOOL INTEGRATION 124, 126 (Murray Friedman et al. eds., 1979) [hereinafter NEW PERSPECTIVES] (citing Reynolds Farley, Racial Integration in the Public Schools, 1967 to 1972, Soc. Focus, Jan. 1975, at 3, 3-26. But see Bruce L. Ackerman, Integration for Subsidized Housing and the Question of Racial Occupancy Controls, 26 STAN. L. REV. 245, 251-60 (1974) (describing the "tipping phenomenon" and offering siatistical evidence of its operation in California and Nevada subsidized housing projects); see also id. at 254 (noting that "expert estimations of tipping points rang[e] from 25 percent black to 60 percent black" (citing Victor S. Navasky, The Benevolent Housing Quota, 6 How. L.J. 30 (1960))).

${ }^{83}$ Cf. Richard A. Wasserstrom, Racism, Sexism, and Preferential Treatment: An Approach to the Topics, 24 UCLA L. REV. 581, 593 (1977) (noting that "[t]he primary evil of [segregation is that it has] designedly and effectively marked off all black persons as degraded, dirty, less than fully developed persons who were unfit for full membership in the political, social, and moral community").

${ }^{84}$ Under City of Richmond v. J. A. Croson Co., 488 U.S. 469 (1989), a "strict scrutiny" analysis will invalidate a "benign" race-conscious program that employs a quota, even if a compelling interest is found in redressing past specific governmental discrimination, because a quota will always fail the "narrowly tailored" tier of the test. Moreover, the Croson Court dealt with a program that employed an access, not a ceiling quota, and was remedial in the sense that it aimed to benefit minorities. The only persons benefited by a ceiling quota to avoid the "tipping" of a project are whites seeking to discourage their communities from becoming "too black." The assertion that nonwhites are benefited in the long run from the "privilege" of living among whites in a balanced ratio-maintained at the cost of nonwhites waiting longer for subsidized apartments than whites-is patently discriminatory. Yet this is the only rationale for allowing ceiling quotas to retard "white flight" that could possibly survive Croson. The devaluation of nonwhites as desirable neighbors invoked by this justification surely runs counter to Croson's strict aversion to stigma: "Classifications based on race carry a danger of stigmatic harm." Id. at 493. 
Furthermore, the Supreme Court has mandated that the judiciary take a long-run view of a world beyond discrimination to avoid crystallizing racist currents into precedent. ${ }^{85}$ The courts cannot be institutions that merely react to and therefore reify racist fears. Rather, courts must be moral leaders by granting relief that forges a standard for race relations and does not resign itself to the sorry state of present affairs. ${ }^{86}$ Even if "white flight" could be articulated definitively by social scientists, it is wholly inappropriate for courts to shape remedies around racist responses, quickening them into concrete law.

\section{A. Tipping and Balancing: The Persistence of the Otero Rule}

Two propositions have emerged from the cases discussing the use of ceiling quotas to maintain integration in assisted housing: one, "tipping" and "white flight" are valid considerations in determining the legality of such quotas; ${ }^{87}$ and two, although strict

${ }^{85}$ See Cooper v. Aaron, 358 U.S. 1, 16 (1958) (holding community opposition irrelevant to African-Americans' right to integrated facilities in Little Rock, Arkansas school desegregation case), discussed in Derrick A. Bell, The Dialectics of School Desegregation, 32 ALA. L. REV. 281, 287 (1981).

${ }^{86}$ See Palmore v. Sidoti, 466 U.S. 429, 433 (1984) ("Private biases may be outside the reach of the law, but the law cannot, directly or indirectly, give them effect."); see also Buchanan v. Warley, 245 U.S. 60, 81 (1917) (reasoning that preservation of public peace cannot justify legal recognition of acknowledged racial prejudice).

${ }^{87}$ In Gladstone, Realtors v. Village of Bellwood, 441 U.S. 91 (1979), the Court, in the process of holding that Bellwood and various "testers" had standing to challenge the invidious "steering" practices of real estate brokers, lent its imprimatur to "white flight." The Gladstone plaintiffs alleged that the steering of black prospective home buyers toward a neighborhood of mixed racial composition and their white counterparts toward a largely white neighborhood "affect[ed] the village's racial composition, replacing what is presently an integrated neighborhood with a segregated one." Id. at 110. Writing for the Court, Justice Powell reasoned:

The adverse consequences attendant upon a 'changing' neighborhood can be profound. If petitioners' steering practices significantly reduce the total number of buyers in the Bellwood housing market, prices may be deflected downward. This phenomenon would be exacerbated if perceptible increases in the minority population directly attributable to racial steering precipitate an exodus of white residents.

Id. (emphasis added).

In the school desegregation context, the Second Circuit has expressly recognized "tipping." In Parent Ass'n of Andrew Jackson High School v. Ambach, 598 F.2d 705 (2d Cir. 1979), the court approved a voluntary desegregation plan that placed a $50 \%$ ceiling on African-American students attending any formerly white school in order to quell white fears that the school would become all minority. The court reasoned: "Although white fears about the admission of minority students are ugly, those fears cannot be disregarded without imperiling integration across the entire system." Id. 
scrutiny is ostensibly the proper instrument for evaluating these programs, a ceiling quota on minorities can stand where the asserted community interest in not "tipping" is large enough. The cases adumbrate the rule that a community's interest in not being "tipped" can legitimize a ceiling quota for minorities within a housing project if the "community" is defined to encompass the geographic neighborhood surrounding the project, rather than just the project itself.

This Section argues that "tipping" is an impermissible consideration in the judicial calculus and that the stigma engendered by ceiling quotas is so discriminatory and disadvantageous to minorities that it fails miserably under any constitutional affirmative action analysis. The cases in this Section share essentially the same basic facts: the defendants maintained a ceiling quota within a housing project and justified it with the claim that absent such a quota the project or the surrounding area would "tip" and become all nonwhite. ${ }^{88}$

Otero v. New York City Housing Authority ${ }^{89}$ is the grandparent of this line of cases and the only one to permit a minority ceiling quota to stand. Although the courts in the cases following had the opportunity to overrule or directly contradict Otero they have left its core intact, merely distinguishing it. ${ }^{90}$ The issue in Otero was whether the New York City Housing Authority's maintenance of a ceiling quota on nonwhites in the rent-up of a new housing project

at 720 .

${ }^{88}$ Yinger notes that ceiling quotas seem like a costless way of diverting nonwhite demand to maintain an integrated project with a lower proportion of nonwhites. See Yinger, supra note 26, at 303 . But, in addition to the moral price, there are economic costs to ceiling quotas: nonwhites must bear the costs of a longer search for housing; they will probably pay more for housing because of the discriminatory frictions in the market; and the areas where the new demand is diverted may exact higher prices as a result of that greater demand. See id.

${ }^{89} 484$ F.2d 1122 (2d Cir. 1973).

${ }^{90}$ See infra notes $96-131$ and accompanying text. The Supreme Court has never directly addressed the question of tipping, although it did confront the opportunity 12 years ago in a Dallas school desegregation case. See Tasby v. Estes, 412 F. Supp. 1192 (N.D. Tex. 1976), remanded, 572 F.2d 1010 (5th Cir. 1978), cert. granted sub nom. Estes v. Metropolitan Branches of the Dallas NAACP, 440 U.S. 906 (1979), cert. dismissed, 444 U.S. 437 (1980). In Tasby, civil rights lawyers challenged an allnonwhite school sub-district and the existence of fifty single-race schools outside of the sub-district on the basis that it was possible to desegregate the entire district. Defendants argued that white flight would negate any efforts at desegregation. The trial court held for the defendants, the Fifth Circuit remanded, and the Supreme Court heard oral argument twice before dismissing certiorari as improvidently granted. See Bell, supra note 85, at 295. 
in an urban renewal area was justified by the interest in "prevent[ing] racial imbalance in the project and in the surrounding community."91 The Second Circuit reversed summary judgment in favor of the plaintiffs, announcing the supremacy of the FHA duty to integrate over the duty to eliminate discrimination: "The [New York City Housing] Authority is obligated to take affirmative steps to promote racial integration even though this may in some instances not operate to the immediate advantage of some nonwhite persons." This rule is made clearer by translating its negative phrasing: integration is an obligation even though it may operate to disadvantage nonwhites. ${ }^{93}$ The discrimination inherent in the devaluation of nonwhite choice is clear in the court's pronouncement that " $[t]$ he affirmative duty ... to promote the policy of fair, integrated housing is not to be put aside whenever racial minorities are willing to accept segregated housing." 94 The implication of this rule is that nonwhites may not legitimately elect to live within predominantly nonwhite communities. ${ }^{95}$

In United States v. Starrett City Associates, ${ }^{96}$ the Second Circuit, striking down a minority ceiling quota, expressly distinguished but did not overrule Otero. Otero's underlying balancing principle survives Starrett City and the other cases discussed in this Section: where the community interested in capping the number of nonwhite

91 Otero, 484 F.2d at 1128 (emphasis added). HUD had relocated 1852 families, $60 \%$ of whom were nonwhite, that had lived in an "Urban Renewal Area" recently acquired by the City. These relocated families were granted first priority in the project being constructed. When the 360 new leases became available, $27 \%$ (rather than the expected $4 \%$ ) of the displaced tenants reapplied for apartments. See id. at 1126. The Housing Authority disregarded its own regulations and preferred white newcomers to nonwhite displaced tenants, creating a $40 \%$ nonwhite to $60 \%$ white ratio that would have been $80 \%$ nonwhite to $20 \%$ white without the ceiling quota. See $i d$. at 1128. The district court granted summary judgment to the plaintiffs. See Otero v. New York City Hous. Auth., 354 F. Supp. 941 (S.D.N.Y.), rev'd, 484 F.2d 1122 (2d Cir. 1973).

92 Otero, 484 F.2d at 1125.

${ }^{93}$ It is interesting to consider the structure of a system that privileges integration absolutely, even where it is maintained by a method tainted by discrimination. Nietzsche elicited the contradictions inherent in any system that maintains itself through precisely the means which it excludes in order to define itself. Another example is the maintenance of a system of "law and order" that excludes violence by means of police and punishment methods that employ violent force. See FrIEDRICH NiEtzsche, ON The Genealogy OF MORAls 97-129 (Walter Kaufmann \& R.J. Hollingdale trans., 1969).

94 Otero, 484 F.2d at 1134 (emphasis added).

95 This view's ramifications are discussed infra notes $133-185$ and accompanying text.

${ }_{96}^{840}$ F.2d 1096 (2d Cir.), cert. denied, 488 U.S. 946 (1988). 
residents is defined broadly enough (i.e. to include the region surrounding the project), it will outweigh the competing interest of nonwhites in not being burdened by stigmatizing quotas.

"Starrett City" is a housing project in Brooklyn, New York, composed of forty-six high-rises containing 5,881 apartments that rents almost exclusively to subsidized moderate- and middle-income tenants. ${ }^{97}$ Defendant-management maintained a strict racial quota of $64 \%$ whites, $22 \%$ African-Americans, and $8 \%$ Hispanics. ${ }^{98}$ The community interest that defendants asserted to justify the quota was "prevent[ing] the loss of white tenants, which would transform Starrett City into a predominantly minority complex. ${ }^{n 99}$ Thus in Starrett City, the community interest was confined to preventing white flight only within the project itself; in Otero, the community interest encompassed the surrounding community, a much broader geographic area.

The Starrett City court, striking down the racial quotas, did not engage in an intensive strict or intermediate level scrutiny analysis and thereby left Otero standing. ${ }^{100}$ If the court had taken into account the intervening Regents of the University of Califormia $v$. $B a k k e^{101}$ and Fullilove v. Klutznick ${ }^{102}$ decisions, it would have recognized that those cases effectively overruled Otero. Instead, it distinguished Otero by noting that Otero "only applied to a single event-the initial rent up of the new complexes." 103 Still, the court discerned an urgency in Otero's preservation of a "precarious racial balance" to prevent "the immediate creation of a 'pocket ghetto" that would "inevitabl[y]" cause "non-white ghettoization'" of the Lower East Side (a broad geographic area). ${ }^{104}$

97 See id. at 1098.

${ }^{98}$ See id. African-Americans waited ten times longer than whites for two-bedroom apartments and almost three times longer on average for one-bedroom apartments. See id. at 1104 (Newman, J., dissenting).

${ }^{99} \mathrm{Id}$. at 1098.

100 See id. at 1101-03.

101438 U.S. 265 (1978) (applying strict scrutiny to invalidate racial quota in school admission plan).

102448 U.S. 448 (1980) (finding that programs employing racial or ethnic criteria must be narrowly tailored to remedy defects of past discrimination).

${ }^{103}$ Starrett City, 840 F.2d at 1103.

${ }^{104}$ Id. (quoting Otero, 484 F. 2d at 1124). The "immediacy" and "inevitability" that Judge. Miner refers to is wholly absent from the Otero opinion: Otero found that nonwhite concentration would "eventually" or "further" occur on the Lower East Side of Manhattan. See Otero, $484 \mathrm{~F} .2 \mathrm{~d}$ at $1124-25$. In addition, Judge Miner's ratification of Otero's blatantly outdated and racist language-"non-white ghettoization"-is disturbing. The implication is that wherever nonwhites (whatever the composition 
The Starrett City court also tried to distinguish Otero on the ground that Starrett City did not aim "to remedy past racial discrimination or imbalance within the complex." 105 The Otero quota, however, did not aim to remedy past discrimination. In addition, the suggestion that Starrett City would be decided differently had its quota been deemed "remedial" misses the point of Fullilove and Bakke's "past discrimination" requirements. As mentioned above, those cases involved quotas aimed to assist, not deter, nonwhite access to a program.

\section{B. The Rule Applied}

Although Burney v. Housing Authority ${ }^{106}$ struck down a quotabased tenanting plan under a strict scrutiny analysis, the court indicated explicitly that the opposite result would have been reached had the community interest side of the balancing equation been defined more broadly. ${ }^{107}$ The Bumey court avoided determining whether the duty to integrate was a compelling governmental interest ${ }^{108}$ by finding that the Beaver plan was not narrowly tailored. ${ }^{109}$

of this vast group) live together a "ghetto" is created.

105 Starrett City, 840 F.2d at 1102.

106551 F. Supp. 746 (W.D. Pa. 1982).

107 See id. at 749. The Housing Authority of the County of Beaver, Pennsylvania managed 1040 family public housing units in sixteen projects located in five geographic districts. The Pennsylvania Human Relations Commission filed a formal complaint against the Housing Authority, charging that the Authority maintained projects segregated by race. By consent decree the Authority and the Commission agreed to desegregate the projects. See $i d$. at 749-50. The method adopted was to set a "target racial balance" equal to the ratio of Blacks to whites in the Beaver public housing system as a whole. When a project deviated from the "target racial balance" tenants of the race whose numbers were deficient would be preferred over tenants whose race was in excess of the target ratio. See id. at 750.

${ }^{108}$ See id. at 764. The court, however, did draw an analogy to the school desegregation cases, and it disagreed with Otero, arguing that "there is no precedent for the ... conclusion that the government has a constitutionally prescribed affirmative action obligation to achieve integration in public housing." Id. at 761 (emphasis in original to distinguish statutory duty imposed by the FHA).

${ }^{109}$ See id. at 765 . The court reasoned that the five geographic districts were themselves segregated by race, adding:

Applicants for housing are placed on waiting lists for projects located in the district where they reside. Thus, a district with a large black population obviously will have a high percentage of black applicants.... [T]he defendant could overcome its ... problem by establishing a countywide waiting list that lists applicants ... throughout the county.... [T] potential for tipping caused by having a large percentage of minority applicants . . . would be eliminated because applicants would be dispersed 
The court ignored its strict scrutiny analysis, however, in carving out the persisting Otero exception. The ceiling quota in Burney was predicated on the prevention of tipping solely within the individual projects. ${ }^{110}$ The defendants made no claim that the quotas were based on their fear that "white flight" would precipitate in the surrounding community. ${ }^{111}$ The court then applied the Otero rule: "The Housing Authority ... did not meet its burden of proving at trial that any existing integrated communities were in danger of tipping because of the percentage of blacks residing in projects located therein." 112 The court further explained that "the Housing Authority must be cognizant of this distinction between neighborhood ... and public housing project transition. ${ }^{\text {113 }}$

The Burney court revealed its acceptance of tipping in being persuaded by the absence of convincing evidence that tipping would have occurred in the Beaver projects. ${ }^{114}$ The court took judicial notice of the specious suggestion that "the tipping point is probably considerably higher in low-income housing projects than in residential neighborhoods. ${ }^{n 115}$ This suggests that the court would have ruled differently had stronger evidence been presented that tipping would occur in the projects, especially if the defendants had shown that "resegregation in the area would almost surely [have] result [ed] in the absence of an integration ceiling."116

The court in United States v. Charlottesville Redevelopment and Housing Authority ${ }^{117}$ did not even reach a strict scrutiny test in striking down a $50 \%$ ceiling quota for African-American tenants in a Charlottesville public housing project. The court realized that

throughout the county rather than being concentrated in one [segregated] district.

Id. at 765. Thus, if the Authority's paramount concern was rapid desegregation with the least intrusion on the right of nonwhite groups to be free from stigma/ discrimination, the county-wide plan was the obvious solution.

${ }^{110}$ The Housing Authority maintained "that the use of a racial access quota [(ceiling quota)] will effectively prevent resegregation by keeping the number of blacks just below the point at which white exodus from and/or white refusal to reside in particular projects is expected to occur." Id. at 758.

111 Such a claim was probably not made because those communities were already segregated. See id. at 765 .

112 Id. (emphasis added).

113 Id. at 767 .

114 See id. (noting that "[f]or example, the Mt. Washington project lost only one white family from 1975-1981 despite the fact that the project was 75\% black").

115 Id.

${ }^{116} I d$. at 766 (emphasis added) (citation omitted).

117718 F. Supp. 461 (W.D. Va. 1989). 
ceiling quotas "seek[] to remedy past discrimination against blacks ... with more discrimination against blacks, ${ }^{n 18}$ that the "unexamined assumption in the Act's legislative history that the principles of nondiscrimination and integration will always ... go hand in hand" is misguided, ${ }^{119}$ and that underlying the "cataclysmic language [of "tipping" discourse] depict[ing] what may occur if a plan giving preference to white applicants does not continue... lies the implicit suggestion that an all black housing constituency is somehow a more enfeebled community." ${ }^{120}$ The court reasoned that when there is a legal and moral conflict between integration and anti-discrimination, "the obligation . . to avoid discrimination must 'trump' [the] obligation to promote integration" whenever ceiling quotas are involved. ${ }^{121}$ Despite the sensitivity of this analysis, the Charlottesville court acquiesced in the Otero/Starrett City rule, affirming the principle that tipping could be a valid justification for upholding a ceiling quota where there is "a threat not simply to the public housing complex but a threat of tipping presented to the entire neighborhood." 122 In the case, however, the interest in promoting white residency was confined to the project itself; it did not encompass the community at large. Therefore, the quota was struck down for lack of a sizable enough asserted interest. ${ }^{123}$

$118 I d$. at 469.

119 Id. at 467.

${ }^{120}$ Id. at $466-67$ n.10.

121 Id. at 468 .

${ }^{122} I d$. at 466 (citing Otero, $484 \mathrm{~F} .2 \mathrm{~d}$ at $1135-36$ ).

123 The Charlottesville court identified the stigma created by the quotas as the fact that "black applicants for spaces in the public housing projects ... have had to wait considerably longer than white applicants" for vacant apartments. Id. at 462. A prior and more elementary stigmatic injury to the plaintiffs in this action, however, inhered in the structure of the Charlottesville system. There was only one project in Charlottesville, and it was rented entirely by African-Americans until the imposition of the quota. Although there was "both a higher percentage of whites who need public housing [based on income] and a larger absolute number of whites who need public housing than blacks [in Charlottesville] ... that white constituency ... [was] thoroughly underrepresented on the lists of applicants for public housing." Id. at 470. Further, there were "limited housing opportunities available to minorities elsewhere [in Charlottesville], due in large part to continued discrimination." Id. at 469 (citation omitted).

The court realized that the manifest reluctance of whites to enter the public housing program reflected a situation where there is an "alleged need [that is] not perceived or even deliberately ignored" by poor whites in Charlottesville. Id. at $470 \mathrm{n} .14$ (emphasis added). The court suggested that whites in Charlottesville simply "do not perceive public housing as a need or as an option which is viable to them," and it neutralized the racist foundations for their preferences by applying Yogi Berra's 
At first glance, Williamsburg Fair Housing Committee v. New York City Housing Authority ${ }^{124}$ seems an anomaly in the preceding line of cases. The defendants, managers of a housing project, maintained a $75 \%$ white, $20 \%$ Hispanic, and $5 \%$ African-American ratio within the Bedford Gardens housing project, although only $30 \%$ of the applicant pool was white. ${ }^{125}$ The defendants justified the quota at trial by arguing that its purpose was to prevent tipping the surrounding area. The court found that the tipping argument was an eleventh-hour justification and was not part of the defendant's actual plan, and, on this reasoning, invalidated the quota. ${ }^{126}$ Thus, Williamsburg, too, is consistent with the Otero rule.

Despite arguing "surrounding area tipping" as a justification for a ceiling quota, in City of Shaker Heights v. Shaker Heights Housing Associates the plaintiffs lost. ${ }^{127}$ The court invalidated a racial ceiling quota not because of its inherent devaluation of nonwhites as desirable neighbors, but because the court found that "tipping is not a relevant concern" since the surrounding area was already $96 \%$ African-American. ${ }^{128}$ Although counsel for defendants argued

aphorism: "If the people don't want to come out to the ballpark, nobody's going to stop them." Id. This dicta essentially sanctions a system that is stigmatizing with and without quotas. As in Bumey, there is a more effective and less stigmatizing remedy to the segregation in the challenged public housing system. Integration could be better achieved by not concentrating all public housing for minorities in one area, especially considering the "limited housing opportunities available . . elsewhere," and also by building among the white community. Id. at 469 .

124493 F. Supp. 1225 (S.D.N.Y. 1980).

125 See id. at 1237. This quota was strictly applied by apartment size, building, and floor. Whites were shown preferred treatment; management met with them more frequently and assigned them nearly all the four-bedroom apartments. See id. at 1251.

126 See id. at 1249-50. Management asserted that it was relying on a Department of Housing Preservation and Development plan to maintain a level of integration in the area, but there was no evidence that the Department had such a plan, and in any case, the Department made no argument that it was currently acting to prevent tipping. See id.

127 No. C85-9, (N.D. Ohio Jan. 23, 1985) (LEXIS, Genfed Library, Dist File). See generally Isabel Wilkerson, One City's 30-Year Crusade for Integration, N.Y. TIMEs, Dec. 30, 1991, at A1. This article discusses Shaker Heights, Ohio's efforts to maintain integrated neighborhoods through subsidized mortgage programs in which members of a racial group are rewarded for moving into a neighborhood where their group is underrepresented. Ninety percent of loans go to whites since few nonwhites can afford real estate in the "districts surrounding the country club." Id. The article notes that "[s]ome black residents see [this] as a degrading approach" and quotes one as feeling that "[w] hen a city will pay to get blacks to move to another community, it sends a powerful message. . . They will do anything to get white people here. The city is bribing them to live next to blacks." Id.

${ }^{128}$ Shaker Heights, No. C85-9, at *9. 
that the interest in not being tipped extended to the surrounding area, that interest weighed very little in the balancing equation because the white community's interest in holding down the nonwhite population in a predominantly nonwhite area was very small (in fact, it was not even "relevant"). ${ }^{129}$

Shaker Heights illustrates well the racist underpinnings of the tipping concept and highlights its inadequacy as a judicial standard. The project, Campbell Court, was originally planned to provide housing for elderly tenants. Because elderly low-income housing tenants tend to be white, the parties anticipated that the project would be approximately $75 \%$ white and $25 \%$ nonwhite. ${ }^{130}$ After viewing a sign at the construction site and reading about the upcoming groundbreaking, however, 500 applicants signed up of whom 63\% were nonwhite. Faced with "segregation" in a project designed to be "integrated," the city sued to enjoin mailing of acceptance letters, requesting an enforced 75-25 white-to-nonwhite quota, which they argued would reflect the "racially balanced" proportions of the city as a whole. ${ }^{131}$

The underlying racism in the tipping discourse is evident. The city deems a $75 \%$ white project "integrated" and desirable, while a $63 \%$ nonwhite project is "segregated" and undesirable. ${ }^{132}$ The presumption that nonwhites are the devalued element in the mix is unavoidable. Furthermore, the City's formulation relies on the notion that a concentration of $75 \%$ whites in a predominantly nonwhite neighborhood will not cause tipping, because the implicit valuation of white over nonwhite will not lead to any "nonwhite flight." In addition, the idea that properly "balanced" communities must have racial proportions reflective of society as a whole robs nonwhite institutions of any claim to equal footing and relegates them to the margins.

${ }^{129}$ See id. at $* 10$. On this reasoning, had the project been built in a white area tipping would have been a relevant concern.

130 See id. at $* 4$.

131 See id. at *5-*6.

132 See Carlo E. Porcelli, Promoting Minority Neighborhoods, Not Integration, (Feb. 14, 1991) (unpublished manuscript, on file with author). 


\section{THE RECOGNITION OF NONWHITE GOMMUNITY IN VOLUNTARY REMEDIES: JUDICIAL RETREAT FROM THE INTEGRATION MINDSET}

The previous Section illustrated how judicial obsession with the goal of integration resulted in treatment of remedies to public housing segregation that sacrificed the anti-discrimination goal of the FHA and equal protection. The discriminatory tipping rationale was sanctioned as a legitimate consideration in the question of how best to achieve integration. The well-meaning goal of integration became discriminatory because the means for achieving it (through consideration of tipping) were inherently discriminatory. This Section explores how, through the process of subsidized housing site selection, the exclusive pursuit of neighborhood integration can inflict discriminatory stigma on nonwhite community.

The first case to consider a challenge to the proposed construction of federally subsidized housing in a nonwhite area was Shannon v. United States Department of Housing and Urban Development. ${ }^{133}$ The plaintiffs were residents of an urban renewal area in Philadelphia who challenged the construction of "Fairmont Manor," an apartment project, claiming that "the location of this type of project on the site chosen will have the effect of increasing the already high concentration of low income black residents in the [urban renewal area]. ${ }^{n 4}$ The Third Circuit found that HUD had only minimal procedures in place for considering the effects of housing placement on racial concentration. ${ }^{135}$ It held these procedures to be inadequate and reversed the lower court's dismissal of the complaint, ordering HUD to "utilize some institutionalized method whereby, in considering site selection ... it has before it the relevant racial and socioeconomic information necessary for compliance with its duties under the 1964 and 1968 Givil Rights Acts. ${ }^{136}$

The Third Circuit's holding in Shannon had the effect of forbidding HUD and local PHAs from locating subsidized housing solely in nonwhite areas. ${ }^{137}$ It established the principle that

\footnotetext{
133436 F.2d 809 (3d Cir. 1970).

134 Id. at $811-12$.

135 See id. at 820-21.

$136 \mathrm{Id}$. at 821.
}

137 See id. at 820 . Oddly enough, considering its progressive effect, the Shannon court couched its rationale in discriminatory terms:

[After] 1964 the administrations of the federal housing programs could [no longer] . . . remain blind to the very real effect that racial concentration has 
discrimination "could arise by virtue of the undue concentration of persons of a given race, or socio-economic group in a given neighborhood" ${ }^{138}$ resulting solely from the choice of location for a given project. HUD adopted this language in 1972, codifying it into new site selection regulations that effectively banished new construction from nonwhite areas. ${ }^{139}$

The regulations have two prongs. The first prohibits new projects from being located in an area of "minority concentration," with two exceptions: the project can be built in such an area if there are "sufficient, comparable opportunities" for minority families in white areas, or if the project is "necessary to meet overriding housing needs which cannot otherwise feasibly be met in that... area. ${ }^{140}$ The second prong stipulates that a site must "promote greater choice of housing opportunities and avoid undue concentration of assisted persons in areas containing a high proportion of low-income persons." 141

These regulations are too extreme in mandating that HUD avoid nonwhite areas when creating new housing opportunities. While dispersal of subsidized housing into suburban and white areas is essential for expanding the access of assisted tenants to a better social services network, more latitude is needed to enable nonwhites to choose to remain within racially and ethnically unified neighborhoods and to rehabilitate those communities, rather than being forced to abandon them. This is not merely a matter of policy:

had [on] urban blight. . . . Increase or maintenance of racial concentration is prima facie likely to lead to urban blight and is thus prima facie at variance with the national housing policy.

Id. at 820-21.

${ }^{138}$ Id. at 820 .

${ }^{139}$ See 24 C.F.R. $\$ 880.206$ (1991) (detailing site selection for Section 8 New Construction) (formerly $\$ 880.112$ ); id. \$ 941.202 (setting forth site selection for construction under federal Public Housing programs); see also Robert C. Farrell, Integrating by Discriminating: Affirmative Action That Disadvantages Minorities, $62 \mathrm{U}$. DET. L. REV. 553, 567 (1985) (discussing HUD's present policy of preferring to deny housing to needy families rather than promote a "segregated" housing system); Duane P. Landreth, Four Elements-Planning, Citizen Participation, Housing Assistance and A-95 Review-Under Title I of the Housing and Community Development Act of 1974, 9 URB. LAW. 61, 108 (1977) (contending that the preamble to the 1974 Housing and Community Development Act is the statutory recognition of Shannon).

${ }^{140} 24$ C.F.R. $\$ 880.206$ (c)(1) (1991).

${ }^{141}$ Id. $\$ 880.206(\mathrm{~d})$. The regulations themselves validate "tipping" as a consideration. See, e.g., id. $\$ 880.206$ (c)(2) ("The site must not be located in ... [a] racially mixed area if the project will cause a significant increase in the proportion of minority to non-minority residents in the area."). 
permitting nonwhite choice is required by the anti-discrimination goal of the FHA and by equal protection. ${ }^{142}$

The dispersal necessitated by the regulations also acts to dilute nonwhite political strength. Whereas the theory motivating current remedies to subsidized housing discrimination is that minorities are better off scattered among the larger white population, current voting rights jurisprudence advocates concentration over dispersal as the preferred vehicle for augmenting minority voting strength. ${ }^{143}$

The HUD regulation, like the judicial reflex of ordering integration, is well-meaning, especially in light of the historical reality that most segregated communities are the product of invidious forces. HUD and the courts should now recognize that the choice of nonwhite groups to remain in group-concentrated neighborhoods may be borne out of valid cultural preferences, rather than out of a reactive sentiment. Subsidized housing tenants, under this view, should be able to choose better housing over integration. Under the present HUD regulations the choice becomes substandard housing or integration.

142 The Shannon court explicitly cautioned that it was not creating an absolute requirement of dispersal:

Nor are we suggesting that desegregation of housing is the only goal of the national housing policy. There will be instances where a pressing case may be made for the rebuilding of a racial ghetto. . . [HUD may] find[] that the need for physical rehabilitation or additional minority housing at the site in question clearly outweighs the disadvantage of increasing or perpetuating racial concentration.

Shannon, $436 \mathrm{~F} .2 \mathrm{~d}$ at 822.

143 See, e.g., Thornburg v. Gingles, 478 U.S. 30, $47-48$ (1986) (finding that multimember districts and at-large voting schemes may be challenged because they may "operate to minimize or cancel out the voting strength of racial [minorities in] the voting population'" (quoting Burns v. Richardson, 384 U.S. 73, 88 (1966))); Whitcomb v. Chavis, 403 U.S. 124, 143 (1971) (same); Major v. Treen, 574 F. Supp. 325 (E.D. La. 1983) (invalidating, under $\S 2$ of the Voting Rights Act, 42 U.S.C. $\S 1973$, a redistricting plan that spread African-American voting strength over two districts, where another plan that had been rejected by the Louisiana state legislature would have consolidated minority voting strength and virtually assured election of a nonwhite representative); Nomination of William Bradford Reynolds To Be Associate Attorney General of the United States: Hearings Before The Senate Committee On The Judiciary, 99th Cong., 1st Sess. 78 (1985) (statement of Senator Biden) ("[T]he rationale, by well-intentioned white folks, to say '[minorities are] really better served having $\mathbf{4 0}$ percent in two districts than having a predominance in one district and electing a Congressperson' ... is so suspect. ... History indicates that that is the rationalization that was almost always used to justify discrimination."). 
A palatable choice for subsidized housing tenants could be provided by broadening the exceptions to the HUD regulations. "Sufficient comparable opportunities" and "overriding need that cannot feasibly be met" are hurdles too high to leap. ${ }^{144}$ The rule should be converted to a rebuttable presumption ${ }^{145}$ that the selection of a new subsidized housing site in an area of nonwhite concentration is motivated by considerations that violate the antidiscrimination provisions of the FHA. The showing of genuine need within a nonwhite community would be sufficient to rebut the presumption.

Further, judicial recourse to integration as the only acceptable remedy to subsidized housing segregation is produced in part by a litigation process that fails to account for the diversity of affected interests. ${ }^{146}$ This problem may be as much rooted in the type of relief plaintiffs request as it is a reflection of the institutional limitations on the judicial role. Under a Plessy jurisprudence, the institution actively devalued nonwhite choice. ${ }^{147}$ Now that the judiciary has recognized the violation, the polar conception of the violation/remedy structure results in an inability to recognize the

144 These requirements can be compared to the "compelling interest standard" of strict scrutiny: it is nearly impossible to fulfill them. See Interview with Ralph Smith, Professor of Law, University of Pennsylvania Law School, in Philadelphia, Pa. (Jan. 14, 1991).

145 Professor Smith suggested this idea of a rebuttable presumption. See id.

146 See Bell, supra note 30, at 505-07. Derrick Bell has articulated the "class action barrier to expression of dissent":

As black disenchantment with racial balance remedies grows, the strongest opposition to civil rights litigation strategy may come from unnamed class members. . . . At one time, expressions of disinterest and even disapproval of civil rights litigation by portions of the class may have been motivated by fear and threats of physical and economic intimidation. But . . . many black parents oppose total reliance on racial balance remedies to cure the effects of school segregation. . . . Black parents who prefer alternative remedies are poorly served by the routine approval of plaintiffs' requests for class status [and for mandatory integration] in school desegregation litigation.

Id. (footnotes omitted). Elaborate discussion of a remedial process that accounts for dissenting, yet affected, voices is beyond the scope of this Comment. For extensive discussion of proposals for public law remedial techniques that account for non-party affected interests, see Susan Sturm, A Normative Theory of Public Law Remedies, 79 GEO. L.J. 1355 (1991).

${ }_{147}$ See, e.g., Missouri ex. rel. Gaines v. Canada, 305 U.S. 337, 349 (1938) (holding that an African-American student, who wished to attend a white law school, must be provided legal education in an African-American school); Berea College v. Kentucky, 211 U.S. 45, 58 (1908) (upholding verdict against a college that provided instruction for both whites and nonwhites in violation of a statute). 
legitimacy of the decision of nonwhites to remain in a nonwhite community.

\section{A. Theoretical Underpinnings for "Nonsegregated" Subsidized Housing and the Recognition of Nonwhite Community}

History raises a high presumption against nonwhites having chosen any degree of segregation. A remedial system, however, that fails to recognize the distinct and valid cultures of nonwhites by forcing dispersal among the larger white community is itself discriminatory. The trick then, is to acknowledge the reality of discrimination while simultaneously preserving the option of a nonreactive desire for nonwhite communities.

The theoretical framework for such a remedy is what Forman and Calmore call "nonsegregation." 148

Nonsegregation implies both the right of people to remain indefinitely where they are, even if in ghetto areas, and the elimination of restrictions on moving into other areas. Nonsegregation would provide for voluntary ghetto residence, while integration could result in involuntary nonghetto residence. Only white ethnocentrism could lead to the belief that all blacks would want to live in predominantly white areas. ${ }^{149}$

Under a nonsegregation analysis the conflicting social science evidence concerning whether nonwhites in general would actually want to remain in nonwhite areas is legally irrelevant. ${ }^{150}$ The

${ }^{148}$ See John O. Calmore, Fair Housing vs. Fair Housing: The Problems with Providing Increased Housing Opportunities Through Spatial Deconcentration, 14 CLEARINGHOUSE REv. 7, 12 (1980).

149 Robert F. Forman, Black Ghetros, WhITE GHETtOS, AND Slums 46 (1971), quoted in Calmore, supra note 148, at 12.

150 See, e.g., Reynolds Farley et al., "Chocolate City, Vanilla Suburbs": Will the Trend Toward Racially Separate Communities Continue?, 7 Soc. SCI. REs. 319, 328-31 (1978) (noting a Detroit survey that indicated 17\% of blacks would prefer to live in all-black communities; only $5 \%$ preferred a predominantly white community), discussed in Potter, supra note 25, at 1170-71. Compare Ackerman, supra note 82, at 266 ("Recent [1968 and 1969] attitude surveys suggest that a solid majority of black families favor housing integration.") with DERRICK A. BELL, JR., RACE, RACISM AND AMERICAN LAW 536 \& n.18 (1980) (arguing that Ackerman's finding "must be viewed with caution" and in the context of the prospect of better housing promised by the integrationist ideal of the post-Brown years). Bell argues further:

Most low-income blacks would prefer better housing close to their present neighborhoods. . . . To the extent that integration policies . . . require them to leave a black neighborhood in order to maintain public housing, blacks may be deprived of the liberty to decide where to live, just as they were 
doctrine of equal protection must be implemented so that genuine choice exists for nonwhites. This is all the more important in the area of subsidized housing, not only for "racial utopia" reasons, ${ }^{151}$ but also because integration of subsidized housing plays the peculiar role of restricting choice under the rubric of expanding opportunity: although the anti-discrimination goal of the FHA aims to eliminate racial barriers to mobility, once a tenant elects to receive government housing assistance she or he surrenders the right to choose location freely in exchange for a subsidy. ${ }^{152}$ To the greatest degree possible then, subsidized housing programs should be administered in a manner that avoids treading on the right to choose, especially since the tenant is participating in the housing program solely because of his or her diminished bargaining power.

The assumption sedimented in the HUD regulations is that an essential ingredient for fair housing, at least in the public sphere, is "whiteness." 153 As has been argued in the school integration

under former segregation policies.

Id. at 556 (citing Comment, 5 HARV. C.R.-C.L. L. REV. 150, 156 (1970)).

${ }^{151}$ See supra text accompanying note 26 (discussing theoretical precision required in subsidized housing).

152 The degree to which mobility is surrendered varies from program to program. Section 8 New Construction substantially restricts mobility, since this type of housing can only be built in areas conforming to the HUD regulations. See 24 C.F.R. $\$ 880.206(c)$ (1991) (describing applicable geographic minority concentration standards). Section 8 Existing Housing subsidies preserve more choice, and thus are more in line with "nonsegregation" because it is primarily up to the tenant to find an apartment. See id. \$ 882.103(a). But even Section 8 Existing units must meet the minimum standards of the program. See id. $\$ 882.109$ (describing applicable housing quality standards). The requirements of the program are more stringent than those set by the decennial census of housing and higher than any other developed by HUD, the Congressional Budget Office, or the Office of Management and Budget. See John C. Weicher, The Voucher/Production Debate, in BuILDING FoundaTIONS, supra note 9, at 263, 267. Many would-be recipients find it difficult to locate a unit that meets these requirements in their neighborhood and are denied the subsidy as a result. See Lorene YaP et al., Lower InCome housing Assistance Program (SECTION 8): Nationwide Evaluation of the Existing Housing Program: Technical SUPPLEMENT 191 (1978) (indicating that 34\% of those denied Section 8 assistance despite qualifying for a certificate said that "finding a unit that would pass Section 8 inspection" was a major problem).

${ }^{153}$ See Derrick A. Bell, Jr., Defining Brown's Integration Remedy for Urban School Systems, in NEW PERSPECTIVES, supra note 82, at 23, 24. Bell develops this idea in the context of school integration:

The assumption that even the attaining of academic skills is worthless unless those skills are acquired in the presence of white students illustrates dramatically how a legal precedent ... has been so constricted even by advocates that its goal . . . . is rendered inaccessible, even unwanted, unless it can be obtained through racial balancing of the school population. 
arena, the legal focus on integration as the only manageable remedy to discrimination has eclipsed the social goal of better housing to the detriment of those in need. ${ }^{154}$ The injury of this eclipsing is not only strangulation of the delivery mechanisms of housing assistance, but also the privileging of white over nonwhite community. ${ }^{155}$

\section{B. Judicial Treatment of the HUD Regulations}

In almost all of the cases in which the prospective building of a new project has been challenged, claiming a violation of 24 C.F.R. $\S 880.206,{ }^{156}$ the courts have made every effort to uphold HUD's approval of the site. Even where the facts indicate that the area is one where minority or assisted persons are concentrated, the courts have found no concentration or have expanded the "overriding need" exception to swallow the rule.

In Business Ass'n of University City v. Landrieu ${ }^{157}$ the court found that the prohibition against locating a site in "an area of minority concentration" was not violated, even though a broader definition of the relevant "area" would have resulted in a violation.

Id.

${ }^{154}$ See Bell, supra note 85. Bell notes that district courts are willing to order school integration, even over the protests of large numbers of African-American parents preferring educational improvement over racial balance, possibly out of exasperation with the frustrating avoidance tactics of resistant school boards. See id. at 294 (discussing Liddell v. Board of Education, 469 F. Supp. 1304, 1330-32 (E.D. Mo. 1979) (ordering further integration despite evidence of affected AfricanAmerican families who preferred "neighborhood" all-African-American schools over busing)); id. at 287 (discussing Lee v. Macon County Board of Education, 616 F.2d 805 (5th Cir. 1980) (ordering integration despite $\mathbf{3 , 0 0 0}$ signatures in support of a petition to save Tuscaloosa's all-African-American Druid High School)). Bell suggests that Brown v. Board of Education, 347 U.S. 483 (1954), stood not only for an integration creed, but also for an education creed. Thus, he argues that integrationists, though pursuing a "praiseworthy goal," should recognize that the goal of promoting the education of minorities can and should be achieved without integration. See Bell, supra note 85, at 283-86.

155 Two commentators argue that nonwhites will endure racial integration as a byproduct of achieving other goals (e.g., access to quality education, responsive police and fire departments, regular garbage collection, low crime rates, good road maintenance), but may not be willing to accept it as a goal in itself. See Leigh \& McGhee, supra note 53, at 34-37. These commentators contend that " $[$ r] esidential racial integration per $s \varepsilon$ is not now and may never have been the desideratum among blacks. The more fundamental concern among black Americans has been freedom from impediments to the fulfillment of their human potential." Id. at 34 .

${ }^{156}$ See supra notes 140-141 and accompanying text.

${ }^{157} 660$ F.2d 867 (3d Cir. 1981). 
The proposed site in West Philadelphia was located at the northern border of a census tract which was only $13.9 \%$ nonwhite, but the adjacent tracts were $23.7 \%$ nonwhite (to the west), $65.3 \%$ nonwhite (to the north), and $98.4 \%$ nonwhite (to the northwest). ${ }^{158}$ In addition, there were two other housing projects predominantly minority occupied, one directly across the street from the proposed site (50\% nonwhite, 448 units) and the other nearby ( $92 \%$ nonwhite, 84 units). ${ }^{159}$ The court, in an opinion by Judge Higginbotham, refused to review substantively HUD's decision because there was no demonstration that HUD had made a "clear error in judgment in defining the relevant area."160 The court held that HUD had "considered the proximity of the already existing low income housing sites and minority impacted census tracts,"161 and "thoughtfully weigh[ed] the question of racial impact," 162 pursuant to the Shannon court's directives and the resulting HUD regulations, and therefore upheld the HUD site selection. ${ }^{163}$

The University City decision reveals a reluctance to read the HUD regulations literally and represents a retreat from the absolute mandate to integrate. Judge Higginbotham encapsulated the problem of the remedial obsession with integration: "Often there is a tendency almost like a hydraulic pressure to expand a doctrine beyond the limits of its logic. ${ }^{n 164}$ The admirable goal of integration can consume the ability to build housing where there is genuine need, which sometimes may mean, in the Shannon court's language, "the rebuilding of a racial ghetto."165

Despite remarkably similar facts, the court in King $v$. Harris ${ }^{166}$

158 See id. at 871.

159. See id.

${ }^{160}$ Id. at 874 (quoting Citizens to Preserve Overton Park v. Volpe, 401 U.S. 402 , $416(1971))$.

161 Id. at 873 .

162 Id. at 874 .

163 Id. at $873,874$.

164 Id. at 878 .

165 Shannon v. United States Dep't of Hous. and Urban Dev., 436 F.2d 809, 822 (3d Cir. 1970); see also supra note 142.

The result in University City can also be understood in light of the court's belief that the motivation for bringing the suit was not necessarily the advancement of the nonwhite interests that the regulations ostensibly aim to protect:

The plaintiffs are responsible business persons who have no animosity against the poor or minorities, and probably would like for all citizens to have decent housing. But, under the guise of their concern about the poor and minorities, business interests would probably acquire this land, and the poor and minorities might be forced to live in areas far more racially 
enforced the regulations in order to advance the goal of integration, blocking a proposed ninety-six unit project in Staten Island, New York. ${ }^{167}$ HUD's approval of the relatively small project was based on a determination that the census tract containing the site was only 12.8\% nonwhite. The court, however, found that HUD had failed adequately to account for several nearby housing projects as well as a concentrated nonwhite population in the general neighborhood, and had confined its analysis "in vacuo" solely to "imaginary census tracts." 168 Alarmed by this, the court predicted that merely introducing these ninety-six apartments would "create an intolerable situation" and "insure the ghettoization of the area,"169 and it consequently issued an injunction.

The King court relied in part on the Second Circuit's decision in Karlen $v$. Harris, ${ }^{170}$ which enjoined the construction of a lowincome housing project in an area containing a high concentration of low-income housing. ${ }^{171}$ The Second Circuit "rejected New York City's low-income housing shortage as a justification for continued concentration of low-income housing in one area." 172 The Supreme Court reversed Karlen in a per curiam opinion that called for judicial deference to HUD. ${ }^{173}$ The opinion stated that a court "cannot 'interject itself within the area of discretion of the executive."174 Justice Marshall dissented, stating that "[t]he issue raised ... is far more difficult than the per curiam opinion suggests .... It is apparent to me that this is not the type of case for a summary disposition." 175 Justice Marshall's call for more

concentrated and poverty-stricken than the proposed housing project ....

University City, $660 \mathrm{~F} .2 \mathrm{~d}$ at 878.

166464 F. Supp. 827 (E.D.N.Y.), aff'd sub nom., King v. Faymor Dev. Co., 614 F.2d 1288 (2d Cir. 1979), vacated, 446 U.S. 905, affd on remand, 636 F.2d 1202 (2d Cir. 1980).

${ }^{167}$ See id.; Farrell, supra note 139, at 567 (stating that King is an "example of judicial preference for integration over housing").

168 See King, 464 F. Supp. at 832-36, 839.

${ }^{169} I d$. at 835 .

170590 F.2d 39 (2d Cir. 1978), rev'd sub nom., Stryker's Bay Neighborhood Council v. Karlen, 444 U.S. 223 (1980) (per curiam).

171 The proposed project was a 17-story high-rise for families to be built on Manhattan's Upper West Side in an area acknowledged as "an already concentrated group of low-income buildings." Id. at 44.

${ }^{1 / 2}$ King, 464 F. Supp. at 843 (relating the Second Circuit's reasoning in Karlen).

${ }^{173}$ See Stryker's Bay Neighborhood Council v. Karlen, 444 U.S. 223 (1980) (per curiam).

174 See id. at 227 (quoting Kleppe v. Sierra Club, 427 U.S. 390, 410 n.21 (1976)).

${ }^{175} I d$. at 228, 281 (Marshall, J., dissenting). 
searching review might have resolved the circuits' vacillation in addressing the regulations. ${ }^{176}$

Two other cases, Aertsen v. Landrieu ${ }^{177}$ and Haakmat v. Pierce $^{178}$ similarly dealt with proposed sites that appeared to violate the regulatory prohibitions, but as in University City, the courts preferred providing housing to integration. Both courts found that the proposed sites were in areas of "minority concentration" but achieved the desired result through a broad reading of the exception clause, which effectively nullified the rule.

In Aertsen, the First Circuit found that the prong prohibiting an "undue concentration of assisted persons" was not violated despite evidence showing that nearly $40 \%$ of the area's population was assisted persons. ${ }^{179}$ Moreover the "area of minority concentration" prong was not satisfied as the parties agreed that the proposed site was in such an area. ${ }^{180}$ To avoid enjoining construction, the court read the exception clause to this prong expansively. It found that the 511 non-minority-area-units that were funded, but not yet in existence, satisfied the exception that a proposed project could be built if "sufficient comparable opportunities exist for minority families ... outside areas of minority concentration." ${ }^{\text {181 }}$

The proposed project in Haakmat clearly violated the regulation's "assisted persons" and "minority concentration" prongs. The area in Staten Island was $71 \%$ minority (the school was $92.7 \%$ minority) and would have had $32 \%$ of the population receiving housing subsidies with the new project. At the time the case was brought, HUD's internal guidelines set $65 \%$ minority as constituting an "area of minority concentration" and $30 \%$ assisted as constituting an "undue concentration of assisted persons." 182 The court found that "[t]here is no doubt that HUD failed to follow its usual

176 The Seventh Circuit decided Alschuler v. Department of Housing and Urban Development, 686 F.2d 472 (7th Cir. 1982), almost solely on the basis of deferring to HUD's expertise in light of Karlen, especially "[g]iven the slippery definition of 'the relevant area,' which turns on numerous objective and subjective factors." Id. at 485 . But see La Plaza Defense League v. Kemp, 742 F. Supp. 792 (S.D.N.Y. 1990) (reversing HUD's approval of a site by finding an undue concentration of assisted persons and enjoining the project from being built in "People's Park").

177637 F.2d 12 (1st Cir. 1980).

178 No. CV-82-1614 (E.D.N.Y. July 12, 1982) (LEXIS, Genfed Library, Dist File).

179 See Aertsen, 637 F.2d at 23.

${ }^{180}$ See id. at 24.

181 Id. (emphasis added) (quoting 24 C.F.R. $\$ 880.206(c)(1)(i)(1991)$ ).

182 See Haakmat, No. CV-82-1614, at *10-*11. 
procedures in approving the development. ${ }^{\text {183 }}$ Yet the court took notice of the critical need for housing and the lack of prospective supply. ${ }^{184}$ It determined that the regulation's exception clause could be invoked: there was "an overriding need for housing which cannot be met elsewhere on Staten Island because of a lack of other feasible sites and proposals." 185

It is thus clear that these courts have read the exception clauses so broadly as effectively to alter the rule. Such a reading is consistent with a recognition of nonwhite community and represents a break from the judiciary's traditional binary view of violation and remedy in this area as discrimination opposed by integration.

In sum, the courts' expansive interpretation of the exception clause to HUD's site selection regulations has put a new spin on subsidized housing jurisprudence. In permitting some subsidized housing to be built in nonwhite areas, the courts are recognizing that the choice to remain in nonwhite community is a legitimate one. This is a great stride towards achieving a more sensitive administration of the anti-discrimination goal of the FHA by incorporating a crucial degree of freedom into the right to choose where one lives. Certainly, were new construction relegated exclusively to nonwhite areas, we would be continuing a "separate and unequal" housing pattern. But the structural deprecation of nonwhite community entailed by a remedial mandate committed solely to forced dispersal is an equally antiquated vision.

\section{CONCLUSION}

This Comment has shown that the exclusive focus on integration as the antidote to past and present discrimination in subsidized housing stigmatizes nonwhites and can operate to deprive them of needed housing. Through its implied view of valid community as white-over-black, integration of site distribution (whether on a small or broad geographical scale) imposes an anglocentric perspective of society and solidifies an already-entrenched racial hierarchy. Allowing subsidized housing to languish primarily in segregated

183 Id. at *4.

${ }^{184}$ See id. at *5 ("If this development is stopped at this point, or even if it is slowed down for a few weeks, 140 new units of housing for the poor will not be built in Staten Island or any place within the city. . . . There is now, and for the next few years will be, no private or public money available to create new housing for the poor.").

${ }^{185}$ Id. at *11. 
neighborhoods would seem to be a surrender of remedial efforts in the face of the herculean task of eradicating racism in housing. But race-conscious efforts at creating or maintaining integration within or around subsidized housing, such as ceiling quotas, inflict far too much stigma to be acceptable vehicles. These concerns are especially cogent given the always-already-subordinated position in which housing beneficiaries find themselves. Further deprecation of recipients' societal worth through theoretically defective administrative methods only exacerbates obstacles to mobility. Respect for choice of location must be paramount in any authentic remedial scheme. 


$$
\text { . }
$$

